\title{
Hemocytes of the carpet shell clam ( Ruditapes decussatus) and the Manila clam (Ruditapes philippinarum): Current knowledge and future prospects
}

\author{
Ludovic Donaghy a, Christophe Lambert b, Kwang-Sik Choi a, Philippe Soudant b*
}

a School of Applied Marine Sciences (POST BK-21), Cheju National University, 66 Jejudaehakno, Jeju 690-756, Republic of Korea

b Université de Bretagne Occidentale, IUEM, LEMAR CNRS UMR 6539, Place Nicolas Copernic, Technopôle Brest-Iroise, 29280 Plouzané, France

\begin{abstract}
Hemocytes are the immune effectors in clams, directing cellular but also humoral defences. In the Manila clam (Ruditapes philippinarum) and the carpet shell clam (Ruditapes decussatus), two phenotypically similar venerid species, fishery and aquaculture importance motivated scientific studies to improve knowledge about the participation of hemocytes in immune response. Currently, gaps still persist concerning the classification of hemocyte sub-populations as well as their non-immune activities. This review summarizes current knowledge about hemocytes of the Manila clam and the carpet shell clam, suggests some probable misinterpretations arising from extrapolations from other bivalves and vertebrates, and suggests future research prospects. The susceptibility of hemocytes to environmental modifications as well as biological and chemical toxicants is also re-evaluated. Hemocytes of bivalves are not limited in function to immunity and should be considered in a wider scheme including the environment and whole-animal physiology.
\end{abstract}

Keywords: Clam; Bivalve; Hemocyte; Immunity; Physiology; Environment ; Homeostasis

* Corresponding author. Tel.: +33 2984986 23; fax: +33 298498545 .

E-mail address: philippe.soudant@univ-brest.fr (P. Soudant).

\section{Introduction}

The clam fishery based on the species Ruditapes decussatus is one of the oldest mollusc fishery practices in Europe and was one of Europe's most important marine resources until the 1960's (Gosling, 2002). For aquaculture purposes, the Manila clam Ruditapes philippinarum was then deliberately introduced as hatchery brood stock into France in 1972 and into the UK and Ireland in 1980 and 1982, respectively (Flassch and Leborgne, 1992; Gosling, 2002). The species Manila clam, native to Japan, Korea, and the Philippines, was introduced accidentally, along with Pacific oysters, into North America during the 1930's. Currently, the Manila clam is distributed widely on Pacific coasts of Canada and the USA, Mediterranean and Atlantic coasts of Western Europe, Korean and Japanese waters, as well as on the East coast of China. In contrast, $R$. decussatus can only be found on the Atlantic coasts of North Africa and Western Europe south of Scandinavian waters (Gosling, 2002). In Europe, $R$. philippinarum proved to be hardier and faster-growing than $R$. decussatus and today contributes $91 \%$ to European yields of the two species. Although both clam species are phenotypically similar, they constitute two distinct entities with high genetic distance (Borsa and Thiriot-Quiévreux, 1990) and a reproductive mating barrier (Gérard, 1978). The Manila clam and the carpet shell clam may be infected by different kinds of pathogens including bacteria and protozoans, resulting in various diseases that sometimes have been associated with mass mortalities (for review, see Bower and McGladdery, 2003; Paillard et al., 2004a). Brown ring disease (BRD), macroscopically characterized by brown conchiolin deposits in the inner surface of the shell, mostly spreads in the northern part of the European Atlantic coast and has been rarely detected below the Loire River and in the Mediterranean and Adriatic seas (Paillard, 2004). The bacterium Vibrio tapetis was sometimes detected and characterized as responsible for BRD in clams. In 2006, a V. tapetis-like bacterium was isolated on the west coast of Korea (Park et al., 2006), possessing a highly similar sequence on partial (413 bp) 16S rDNA sequence, from R. philippinarum showing brown deposits. BRD, however, could also be observed without isolation of a bacterial agent. For instance, brown conchiolin deposits can be observed in trematode-infected clams (Park and Choi, personal communication) as well as on clams with fungal or annelid disturbances of the pallial edges of bivalve shells (Paillard, 2004). Clams presenting BRD may show significant weight loss during late stages of the disease (Flye-Sainte-Marie et al., 2007), modified defense-associated activities, and ultimately mass mortality (Paillard et al., 1989, 2004a; Allam et al., 2000; Paillard, 2004). Perkinsosis, induced by protozoan parasites Perkinsus sp., 
is also one of the major, infectious diseases affecting clams. In Europe, west and south coasts of Korea, in Japanese waters, and along the northern coast of the Yellow Sea in China, Perkinsus olseni frequently induces the formation of visible, milky-white cysts or nodule on the gills, foot, gut, digestive gland, kidney, gonad, and mantle of heavily-infected clams. The massive aggregation of Perkinsus sp. and hemocytes sometimes forms lesions that may interfere with respiration and other physiological processes such as reproduction, growth and/or survival and thus have an impact on fishery productivity (Hamaguchi et al., 1998; Park et al., 1999; Liang et al., 2001; Choi et al., 2005). Despite the large economic and ecological importance of this living resource, scientific research in marine bivalve pathology has traditionally been essentially descriptive, focusing on pathogen morphology, anatomopathology and epidemiology. Progress has been made in experimental pathology with the isolation and purification of several pathogens. Besides the preparation of specific molecular probes to diagnose the presence of potential or known pathogenic agents, the availability of purified pathogens allowed the development of in vivo and in vitro models for studying host- pathogen interactions, with a special emphasis on host defence processes (Bachère et al., 1995). Clams, as other bivalves, have developed an open, hemolymphatic circulatory system. Hemocytes are circulating cells which act as sentry cells, scanning the immediate environment to detect foreign material and induce efficient immune responses. The major importance of hemocytes as cellular immune effectors in marine bivalves was already pointed out in the early 70's (Cheney, 1971). Although hemocytes are involved in various physiological processes, including tissue repair, shell production, and nutrition, they were mostly studied for their implication in immunity and elimination of pathogens in fishery and aquaculture contexts. Consequently, hemopoiesis, life cycle, and non-immune functions of the hemocytes are not well characterized at present. Furthermore, current knowledge and understanding of hemocyte biology were sometimes extrapolated from vertebrate biology and immunology, potentially leading to misinterpretations.

Objectives of this review are (i) to summarize current knowledge about hemocytes of the clam species, $R$. decussatus and $R$. philippinarum, (ii) to point out some probable misinterpretations and (iii) to suggest possible future research prospects. In the Manila clam and the carpet shell clam, classification of hemocyte subpopulations according to morphological and cytological features may not match functional reality and, until now, does not fully elucidate hemopoiesis in the clams (Section 1). Section 2 summarizes the extensive knowledge regarding the implication of hemocytes in cellular and humoral immune responses of clams. This section also identifies extrapolations from other bivalve and vertebrate models, and suggests potential research prospects in non-immune functions of hemocytes. Finally, Section 3 considers the important function of hemocytes in clam homeostasis and the rapid and specific adaptations of these cells to environmental modifications. Susceptibility of clam hemocytes to biological and chemical toxicants is also reviewed and re-interpreted.

\subsection{Hemocyte types of the Manila clam and the carpet shell clam}

In marine bivalves, two main hemocyte types were described according to morphological features: granulocytes, which contain numerous granules within the cytoplasm, and agranulocytes also called hyalinocytes, without granules (For reviews see Cheng, 1981; Hine, 1999). The granulocyte subset is homogeneous; whereas, subpopulations of agranulocytes were observed in some but not all bivalve species, such as small and large hyalinocytes in Crassostrea virginica and Ostrea edulis (AshtonAlcox and Ford, 1998; Xue et al., 2001; Hégaret et al., 2003a; Bigas et al., 2006), intermediate cells in C. virginica (Goedken and DeGuise, 2004), small agranulocytes in Crassostrea gigas (Lambert et al., 2003, 2007a; Labreuche et al., 2006) and blast-like cells in R. philippinarum (Cima et al., 2000), in the Sydney rock oyster Saccostrea glomerata (Aladaileh et al., 2007) and in the Suminoe oyster Crassostrea ariakensis (Donaghy et al., 2009). As expected, both granulocyte and hyalinocyte populations were observed in the Manila clam (Cima et al., 2000) and the carpet shell clam (Auffret, 1985; López et al., 1997a). Although some authors reported differences in size between granulocytes and hyalinocytes, these two cell types seem to possess similar ranges of diameter approximately 10 $\mu \mathrm{m}$. Actually, disparities among studies often resulted from the use of various investigation methods. For instance, López et al. (1997a) compared cell size between spread hemocytes and the same cells fixed in suspension. Granulocytes were then reported as the largest cells when spreading on slides but not in suspension. Flow cytometric analysis of Manila clam hemocytes showed hyalinocytes as larger cells than granulocytes, according to the values of the forward scatter in arbitrary unit (Fig. 1). Although the size of the nuclei also varied between slides and suspension, the nucleus/cytoplasm ( $N /$ C) ratio of granulocytes and hyalinocytes remained equal between the two cell types (López et al., 1997a). Discrepancies between authors also concerned the proportion of each population (differential hemocyte count=DHC) in clam hemolymph. First, such discrepancies can reflect the method used for observation (Ashton-Alcox and Ford, 1998). Certainly, differences of DHC in clams are associated with 
environmental conditions (rearing sites and seasons) (Soudant et al., 2004; Flye-Sainte-Marie et al., 2009). Inter-individual variation (Xue et al., 2001) and genetic origin (Delaporte et al., 2007a; Lambert et al., 2007b) were also demonstrated to influence DHC in oysters. Many other biotic and abiotic factors, such as reproduction, parasitism, food availability, temperature, and pollutants, can also modulate DHC in bivalves (Fisher et al., 1996; Carballal et al., 1998). Granulocytes and hyalinocytes exhibit the same common eukaryotic organelles in their cytoplasm, such as various quantities of mitochondria, Golgi apparatus, endoplasmic reticuloma and a nucleus that can be oval or round, and eccentric, or central (Auffret, 1985; López et al., 1997a). Historically, another distinction was made between these two cell types on the basis of the low capacity of hyalinocytes to spread and to adhere to plastic (López et al., 1997a). However, in $R$. philippinarum, Cimaet al. (2000) reported both hyalinocytes and granulocytes as round hemocytes (spherical shape) but also as spreading hemocytes (amoebocyte shape) and observed that hyalinocytes were also able to extend pseudopodia. The sole ultrastructural feature by which one can unequivocally distinguish both cell types is the presence of numerous granules in the cytoplasm of granulocytes (Cheng, 1981; Auffret, 1985; López et al., 1997a; Hine, 1999; Cima et al., 2000). On the basis of different dye affinities of cytoplasmic granules, López et al. (1997a) categorized the granulocytes of $R$. decussatus into two subpopulations (basophils and acidophils); whereas, Cima et al. (2000) characterized the granulocytes of $R$. philippinarum into three subpopulations: basophils, acidophils and neutrophils. Cheng (1981) suggested that the occurrence of various types of granules might be related to differentiation and maturation processes; specifically, basophilic granules were hypothesized to be immature granules which mature and become acidophilic. The simultaneous occurrence of both kinds of granules within some hemocytes in $R$. decussatus and $R$. philippinarum might support this hypothesis (López et al., 1997a). Diverse theories have been proposed to elucidate the hemocyte lineage. Cheng (1981) and Auffret (1988), based on the observation of granules in some blast-like cells, proposed two types of cell precursors which differentiate into granulocytes and hyalinocytes. More recently, Hine (1999) reviewed those statements and, in the absence of granuloblasts, suggested a model with only one precursor cell type giving rise to hyalinocytes which further mature into granulocytes. A single population of blast-like cells lacking granules in their cytoplasm was described in $R$. philippinarum (Cima et al., 2000; Matozzo et al., 2008) supporting the hypothesis presented by Hine (1999). Circulating hemocytes of $R$. decussatus and $R$. philippinarum have been mainly studied from the hemolymph compartment, but, as there is an open hemolymphatic circulatory system of clams, hemocytes also have been isolated in central and peripheral extrapallial fluids from $R$. philippinarum clams (Allam and Paillard, 1998). These fluids are considered to be the sites of biomineralization, but roles of these fluid compartments in other biological processes, such as host defense, remain unknown. Hemocytes described in these fluids share the same morphological and cytological characteristics with the hemocytes from hemolymph. Morphological characterisation, thus, does not allow exact classification of hemocyte sub-populations in clams. A further step in the definition of hemocyte subsets could be to improve the description of population-related molecular markers and the subsequent production of specific antibodies. In bivalve species, monoclonal antibodies (MAbs) were raised against isolated hemocytes of the mussel Mytilus edulis (Noël et al., 1991, 1994); these antibodies allowed the distinction between 3 groups of hemocytes: (i) basophilic granulocytes, (ii) eosinophilic granulocytes, and (iii) both basophilic granulocytes and hyalinocytes (Dyrynda et al., 1997). Carballal et al. (1997a) determined possible cross-reactivity among mussel species. MAbs developed against the hemocytes of $M$. edulis (Noël et al., 1991) reacted with the hemocytes of Mytilus galloprovincialis, and one of the MAbs exhibited specificity for the basophilic granulocytes. In the clam species $R$. decussatus, López et al. (1997a) attempted to distinguish different hemocyte populations with MAbs raised against the hemocytes of C. gigas (Morvan, 1991) and M. edulis (Noël et al., 1994). Cross reaction was observed with only a few MAbs developed against the hemocytes of $C$. gigas. In the oyster species $O$. edulis, one MAb specifically recognized granulocytes, allowing flow cytometric and histological studies (Renault et al., 2001; Xue and Renault, 2001). Finally, 4 MAbs were developed against the hemocytes of the scallop Chlamys farreri, but these bound to more than one hemocyte type (Xing and Zhan, 2005) and cross-reacted with at least six other bivalve species (Xing and Zhan, 2006). This antibody method was developed for the broad characterization of human and murine immune cells. As reported by Naik (2008), "prior to the 1970s, lymphocytes were regarded as an indistinguishable group of cells, primarily because they appeared identical under the light microscope". About 40 years later, it seems that a new immune-cell subset is still discovered almost seasonally. The multiplication of markers and subsets, however, sometimes leads to mistakes. A an example of such a mistake is the "extraordinary" discovery of interferon-producing killer dendritic cells (IKDCs), a new subset of murine dendritic cells (the main antigen presenting cells of mammal immune system; DC). This "revolutionary" DC subset was presumed to share phenotypic and functional 
properties of both DCs and natural killer (NK) cells (Chan et al., 2006; Taieb et al., 2006). Two years later, IKDCs were finally demonstrated as only one subset of NK cells, sharing a molecular marker with a DC subset, but sharing absolutely no functional properties (Blasius et al., 2008; Caminschi et al. 2008; Vosshenrich et al., 2008). In bivalves, the identification of molecular-defined hemocyte subsets should be relevant if such classification can be related to different functional properties. Indeed, an alternative might be the classification of hemocyte types depending upon the function studied and relative activities. In this way, recent development of powerful tools, such as flow cytometry, in bivalve cellular biology allows the analysis of activities at the single cell level and the appreciation that hemocyte subsets may respond very differently in various physiological measurements.

\section{Functions of hemocytes}

As previously stated, hemocyte sub-populations may be differentially involved in functions of bivalve biology and physiology, including nutrient transport and digestion, tissue and shell formation, maintenance of homeostasis, and immune response (Cheng, 1996, 2000; Chu, 2000). As stated above, currently, the main function of hemocytes of clams studied thus far is immune response. In bivalves, cellular-defence mechanisms against foreign, biological material can be summarized in five steps: 1) chemotaxis, 2) opsonization, 3) recognition of non-self particles, 4) phagocytosis, and then 5) intracellular degradation of foreign material (Fig. 2). These steps have not yet been described completely in $R$. decussatus and $R$. philippinarum, thus it can only be assumed that these phenomena occur in clams as in other bivalves.

\subsection{Chemotaxis}

Following the detection of foreign material in the hemolymph or in tissues of clams, competent cells then migrate to the affected site. The active migration of hemocytes is induced and regulated by soluble molecules named chemotaxins, released either by the foreign agent or by host cells. Migration of the hemocytes in response to such mediators is called chemotaxis. In clam species, very few in vitro studies have been performed to monitor the responses of isolated hemocytes to foreign, biological agents. Three strains of $V$. tapetis and one strain of Escherichia coli induced chemotaxis of isolated hemocytes from $R$. decussatus and $R$. philippinarum (Lopez-Cortes et al., 1999); whereas, hemocytes from the hard clam Mercenaria mercenaria were shown to migrate toward chemical products secreted by E. coli (Fawcett and Tripp, 1994). Currently, only a few chemotaxins have been identified in molluscs other than clams, including lipopolysaccharide in $M$. edulis (Schneeweiss and Renwrantz, 1993), formyl-methionyl-leucyl-phenylalanine in M. mercenaria (Fawcett and Tripp, 1994) and interleukin-8 in M. galloprovincialis (Ottaviani et al., 2000). Currently, most existing data concerning chemotaxis of hemocytes in clams has been reported in vivo. Indeed, observation of milkywhite nodules on the surface of mantle, gill, and foot tissue is a common feature of Perkinsus-infected R. philippinarum (Fig. 3). Histological studies demonstrated that these nodules were formed by inflammation as a consequence of a massive hemocyte infiltration into tissues (granuloma structure), surrounding Perkinsus trophozoites (Fig. 4), suggesting active migration of hemocytes from hemolymph into tissues (Lee et al., 2001; Park and Choi, 2001; Choi et al., 2005). Similarly, exposure of Manila clams to the harmful alga Prorocentrum minimum was reported to also induce an inflammatory response, characterized by massive hemocyte incursion into the digestive glands, intestine and stomach, as well as in the gonadal follicles from which hemocytes are ordinarily excluded (Hégaret et al., 2009). Chemotaxis is not exclusively related to immune responses and may constitute an active part in all functions of hemocytes, such as nutrition or tissue and shell repair. For example, it may be hypothesized that nutrient-carrier hemocytes, through recognition of molecular signals, would specifically migrate and supply nutrients to tissues most in need. In the scallop Pecten maximus, Beninger et al. (2003) reported the migration of ferritin-bearing hemocytes from the digestive system to oocytes. The ferritin was initially taken up into the intestinal epithelium, subsequently appearing in hemocytes among the connective tissue surrounding the intestine. Ferritin-carrier hemocytes then migrated to reach the gonad and were observed in close proximity to oocytes. Interestingly, this transport of ferritin by hemocytes was specifically dedicated to developing oocytes: first, ferritincontaining hemocytes were readily observed near developing oocytes, which accumulate substantial vitelline reserves. Contrastingly, such hemocytes were rarely observed within male gonad acini which produce small spermatozoa with low energy reserves. Second, ferritin-containing hemocytes were always associated with developing oocytes and never with mature oocytes. These facts tend to confirm that nutrient-carrier hemocytes specifically migrated towards developing oocytes through recognition of molecular signals. Another example of non-immune related chemotaxis may be the migration of bivalve hemocytes to a shell-repair edge. In 2004, Mount et al. reported a class of granulocytic hemocytes that might be directly involved in crystal production during shell regeneration 
in the eastern oyster $C$. virginica. After notching the shell of oysters, crystal-bearing hemocytes appeared at the mineralization front. Hemocytes implicated in shell repair may then have migrated through chemotaxis. In immune-related hemocyte infiltration, however, and in both examples of nonimmune chemotaxis, the nature of the chemotactic signal is currently unknown. Characterization of chemotaxins and differential involvement of hemocyte sub-populations should be the next steps in understanding chemotaxis in bivalves.

\subsection{Secretion of soluble factors}

Secretion of soluble factors by hemocytes plays an important role in the immunity of $R$. philippinarum and $R$. decussatus. This humoral response involves various molecules such as lectins, lysins and antimicrobial peptides (AMPs). An important humoral-defense mechanism is the agglutination of foreign material, such as bacteria and parasites, to facilitate the inactivation of such pathogens and/or to activate/improve hemocyte activity. This is the first step in the process of recognition and subsequent internalization of the agglutinated material by the host hemocytes (Chu, 1988). Lectins are soluble or membrane-bound factors that recognize specifically, and bind reversibly to, the carbohydrate-containing molecules of foreign cells. Lectins appear to participate in the tagging of foreign organisms by invertebrates, which are covered with different carbohydrate receptors. Lectins play agglutinating and opsonising roles, facilitating interaction of the surface of hemocytes with foreign particles (Fig. 5). Ordás et al. (2000a) observed relatively-high agglutination titers among $R$. decussatus clams that were heavily parasitized with $P$. olseni, which suggests that a lectin-like substance may be involved in immune response against this parasite. In 2006, Kang et al. constructed a cDNA library from Manila clams infected with $P$. olseni. They found 79 ESTs related to 29 functional immune genes. Among these ESTs, the largest group was composed of lectins. The lectins MCL and MCL3 have been characterized in $R$. philippinarum clams and were upregulated during $P$. olseni infection (Bulgakov et al., 2004; Kang et al., 2006; Kim et al., 2006, 2008a).MCL3 was also detected in clams one day after intramuscular injection of $V$. tapetis (Kim et al., 2008a). Kim et al. (2006) showed: (i) that MCL was able to bind to the surfaces of purified $P$. olseni hypnospores and zoospores; and (ii) that fluorescent beads coated with purified MCL were actively engulfed by hemocytes through phagocytosis. These authors suggested that MCL could act as an opsonin through recognition of residues on $P$. olseni parasite cells. Takahashi et al. (2008) also purified another lectin isoform from $R$. philippinarum, MCL4 that might also contribute to the clam immune response against invading microorganisms. Indeed, the phagocytic abilities of the hemocytes from $R$. philippinarum for the bacteria Marinococcus halophilus and Vibrio tubiashii were significantly increased when bacterial cellswere oposonized with MCL4. Recently, the gene sequence for a member of the galectin family of lectins, MCGal, was cloned in R. philippinarum clams (Kimet al., 2008b). Expression of this gene was also up-regulated in clams infected with Perkinsus parasites or Vibrio bacteria, compared with healthy clams. Finally, it is interesting to note that hemocytes from Perkinsus-infected clams expressed different sets of lectins than clams with a Vibrio infection, indicating that induction of lectin isoforms seems to be specifically related to the nature of the infective microorganism (Kang et al., 2006). Antimicrobial peptides (AMPs) are also soluble substances secreted in the hemolymph by hemocytes during the infection process. These molecules represent an ancient mechanism of host defense and constitute an important component of the clam immune system. According to primary structure and consensus cysteine array, these peptides were classified into four groups: mytilins, myticins, defensins, and mytimicins. Three different myticin isoforms, and one mytilin, were identified in hemocytes from bacteria-stimulated $R$. decussatus. These peptide sequences displayed similarity with known mussel mytilin and myticin genes (Gestal et al., 2007). Defensins have been isolated from mammals and insects, and other invertebrates and characterized as effector molecules of innate immunity (Ganz, 1999). Five ESTs identified from $P$. olseni-infected $R$. philippinarum showed similarities with a defensin-like peptide, MGD1, previously described in the plasma and hemocytes of the Mediterranean mussel (MGD1=M. galloprovincialis defensin-1) (Kang et al., 2006). This AMP, however, was not reported in hemocytes from bacteria challenged $R$. decussatus clams (Gestal et al., 2007). Until recently, the opsonic and lytic complement system was thought to exclusively belong to vertebrates. Recent work in $P$. olseni infected $R$. decussatus clams, however, identified transcripts matching to proteins involved in complement signalling, such as $\mathrm{Rd}$ adiponectin- $\mathrm{C} 1 \mathrm{q}$ and a multidomain protein with similarity to complement related domains (Prado-Alvarez et al., 2008). These authors also identified several ESTs with a C1q domain that could be related to the lectin complement pathway in innate immunity, closely related to the classical complement pathway in adaptive immunity of vertebrates. In this case, comparisons with vertebrate gene banks allowed determination of sequence homologies of newly-identified ESTs in bivalves and associated information about putative functions. 
There is also a potential risk, however, of assuming relations between sequences that might have no truth in bivalve cell biology.

\subsection{Encapsulation}

As described in Section 2.1, milky white nodules can be observed macroscopically in Perkinsusinfected clam tissues. In these nodules, parasite trophozoites were found, surrounded by a capsule mainly composed of eosinophilic, granular hemocytes (Fig. 6) (Lee et al., 2001; Park and Choi, 2001; Choi et al., 2005). In 1987, Chagot et al. (1987) first described this inflammatory reaction in $R$. decussatus infected with Perkinsus parasites. In the connective tissues of various organs, the inflammatory response induced granuloma-like lesions in which parasites were frequently encysted and surrounded by granulocytes. This was the first observation of the capacity of hemocytes of $R$. decussatus to encapsulate Perkinsus trophozoites. Eight years later, Montes et al. (1995a) and Sagristà et al. (1995) concomitantly described this inflammatory response in $R$. philippinarum clams infected with Perkinsus parasites. Granulocytes also were found to be involved in the secretion giving rise to the encapsulation of the parasites. The specific, defensive hemocyte product was characterized as a slightly glycosylated polypeptide and named polypeptide p225 (Montes et al., 1995b). The secretion of a polypeptide closely related to p225 was also observed in $R$. decussatus (Montes et al., 1996). Interestingly, this polypeptide was absent from non-parasitized $R$. philippinarum clams, suggesting the specific and exclusive association of p225 with Perkinsus infection (Montes et al., 1995b) (Fig. 7). The encapsulation process is commonly thought to be induced to control parasites that hemocytes are not able to phagocyte. For instance, Sagristà et al. (1995) observed that Perkinsus sp. trophozoites were first located within the host granular cells, but phagocytosis was not successfully completed as lysis of hemocytes finally occurred. Release of protein secretion then gave rise to a capsule to control free parasites. Currently, the fate of parasites inside the capsule is unknown. Montes et al. (1995b) suggested that "the diffusion of this polypeptide (ND: p225), and probably other molecules from the capsule, across the trophozoite wall, and accumulation in the invaginations of the plasma membrane, could have a negative effect on the viability of the trophozoites". Mechanisms of parasite degradation inside the capsule, however, still have not been described and should therefore be further investigated.

\subsection{Phagocytosis}

The major cellular mechanism involved in the hemocyte-mediated immune response of marine bivalves, and probably the most studied, is the internalization of antigenic material (Canesi et al., 2002). Recognition and binding of non-self material by receptors expressed at the surface of the hemocytes induce the mechanism of internalization called phagocytosis. In clams, engulfment of foreign particles by hemocytes occurs by invagination of the cell membrane followed by pseudopod formation and particle internalization into an endocytic vacuole, also called the primary phagosome. Cytoplasmic lysosomal granules then migrate and fuse with the primary phagosome. Contents of granules, i.e. numerous hydrolases, including phosphatases, esterases, amidases, as well as carbohydrate hydrolases, and oxidative enzymes such as peroxidase and cytochrome c oxidase (López et al., 1997b; Cima et al., 2000), are subsequently discharged in the so-called secondary phagosome, accomplishing the enzymatic degradation of engulfed foreign material (López et al., 1997c). In the carpet shell clam and the Manila clam, phagocytic capability was described for both granulocytes and hyalinocytes (López et al., 1997c; Cima et al., 2000). Although circulating granulocytes and hyalinocytes from both $R$. decussatus and $R$. philippinarum are able to internalize yeast cells, bacteria, and protozoan parasites (López et al., 1997c; Cima et al., 2000), differences were observed in terms of the phagocytic index between the two hemocyte populations or the clam species (López et al., 1997c; Lopez-Cortes et al., 1999). Granulocytes are the most powerfullyphagocytic cells, possessing a constantly high phagocytic index (in this case, the percentage of cells having ingested zymosan particles or Vibrio P1 cells, regardless of the quantity of ingested material); whereas, the phagocytic index of hyalinocytes seemed related to the nature of the foreign material (López et al., 1997c). Such observations suggest functional differences between hemocyte types and receptor-based initiation of phagocytosis. This latter point is also supported by the observation that granulocytes and hyalinocytes were able to engulf trophozoites but not zoospores from the $P$. olseni parasite (López et al., 1997c). Interestingly, phagocytosis seems inhibited by $P$. olseni, as heavy infection with $P$. olseni in $R$. decussatus and $R$. philippinarum tended to decrease phagocytic capacities (Ordás et al., 2000a; Flye-Sainte-Marie et al., 2009). Lysosomal enzymes actively participate in the killing and degradation of engulfed foreign material. Various enzymatic activities were detected in both granulocytes and hyalinocytes from $R$. decussatus and $R$. philippinarum (López et al., 1997b; Cima et al., 2000), but distribution of these enzymes was not homogeneous in the two 
hemocyte subsets, confirming differential involvement in physiological and immune responses (Cima et al., 2000). Among these enzymes, lysozyme, a central lysosomal enzyme with bacteriolytic properties (McHenery et al., 1986), was detected both intracellularly and as a soluble factor in the hemolymph of $R$. philippinarum and $R$. decussatus (López et al., 1997b; Soudant et al., 2004). In clams and oysters infected with, respectively, $P$. olseni and $P$. marinus, there was either no difference (Chu and La Peyre, 1989, 1993a; Chu et al., 1993; Ordás et al., 2000a), a slight decrease (La Peyre et al., 1995; Garreis et al., 1996), or an increase of lysozyme activity (Chu and La Peyre, 1993b). It has been suggested that changes in lysozyme activity may be related to environmental factors such as temperature and salinity (Steinert and Pickwell, 1985; Fisher and Newell, 1986; Chu, 1988) rather than infection status. Actually, lysozyme content and environmental conditions are also difficult to correlate. In other bivalve models, although several studies described a seasonal pattern with higher lysozyme content during winter and lower values during the summer (Chu and La Peyre, 1989; Chu et al., 1995; Volety et al., 1999), Fisher et al. (1996) observed higher lysozyme levels in July and lower levels during fall and winter. Finally, Soudant et al. (2004) observed no seasonal pattern for the lysozyme content in hemolymph of $R$. philippinarum. In this study, lysozyme content appeared to depend upon the location of rearing sites. These authors suggested that, in this case, variations in food availability and quality might explain lysozyme content in clams. These authors argued that lysozyme-induced digestion of bacteria might form a significant part of the bivalve diet (McHenery et al., 1986). A large emphasis is put today on the study of phagocytosis in the context of immunity and host-pathogen interaction. Although this is undoubtedly an essential aspect of phagocytosis, this mechanism of internalization was first a non-immune process in early eukaryote evolution. Indeed, in unicellular organisms, phagocytosis is a digestive cellular process used for the intake of nutrients (Desjardins et al., 2005). Interestingly, self/non-self recognition mechanisms, opsonin like substances, and signal transduction elements were also described in unicellular organisms such as the amoeba Dictyostelium sp., although these processes were previously considered to be extant only in higher organisms (Lewis and O'Day, 2007). This already-complex and efficient cellular digestive system defines the primary function around which phagosomes expended their functional abilities throughout evolution (Desjardins et al., 2005). In multicellular organisms, concomitantly with the development of nutrition dedicated organs, phagocytosis evolved into immunity mechanisms. In bivalves, little is known about whether nutrient uptake through hemocyte phagocytosis may act as an active nutritional process or as an accessory mechanism only recycling immune response residues. There are, however, few clues suggesting an active role of hemocytes in nutrition of bivalves. Indeed, phagocytic hemocytes of bivalves produce and accumulate large amounts of glycogen, the energy-storage form of glucose (Cheng, 1975). Glycogen accumulation was detected in granules of hemocytes from various bivalve species, including the oysters C. ariakensis (Sun et al., 2006), C. virginica (HarrisYoung et al., 1995), the mussel M. galloprovincialis (Cajaraville and Pal, 1995) and the clams Meretrix meretrix (Zhang et al., 2005) and $R$. decussatus (López et al., 1997c). Interestingly, Hégaret (2007) suggested the involvement of hemocytes in nutrition to be different between oysters and clams, as oysters possess phagocytic digestive cells but clam digestive cells function by the process of pinocytosis (i.e., the ingestion of small drops of dissolved materials). In the mollusc species Haliotis tuberculata, glycogen was also observed in granules of phagocytic hemocytes (Travers et al., 2008). Flow-cytometric investigation revealed that, in fasted animals, glycogen content was low and increased when feeding occurred (Travers, personal communication). The question may be raised, however, whether or not lysozyme molecules expressed by hemocytes are effectively implicated in digestion. Actually, high lysozyme activity was detected in the digestive systems of many bivalves (Mochizuki and Matsumira, 1983; McHenery et al., 1986; Takahashi et al., 1986). The use of bacteria as a food supply by some marine bivalves was reported (McHenery and Birkbeck, 1985; Langdon and Newell, 1990), and lysozyme content in clams varied with food availability (Soudant et al., 2004). Currently, however, no well-defined information is available about either the production of digestiveimplicated lysozyme by bivalve hemocytes or the differential involvement of hemocyte populations in such processes. Indeed, in the oyster $C$. virginica the molecule cv-lysozyme 1 was mainly expressed in mantle, labial palps, gills and to a lesser extent in hemocytes (Itoh et al., 2007), suggesting a role in oyster defense, while cvlysozyme 2 was mostly expressed in digestive-gland tissues (Xue et al., 2007) indicating a role in digestion. In the Pacific oyster $C$. gigas, however, a lysozyme molecule was detected both in digestive organs and circulating hemocytes (Matsumoto et al., 2006). Further investigation is then required to clarify the biological functions of lysozymes in bivalves and the implication of hemocytes in digestion. Finally, phagocytosis is also applied during embryogenesis for the removal of dying cells and the recycling of their molecules, as well as tissue remodelling in multicellular organisms (Desjardins et al., 2005). Hemocyte populations in bivalves might then be differentially involved in nutrition, embryogenesis, and tissue remodelling processes. It can be 
hypothesized that a decrease in hemocyte-related immune parameters might then be attributable to a higher implication of these cells in another physiological function. It should therefore be important to concomitantly measure immune and non-immune parameters of hemocytes. Further investigations still are needed to better understand and characterize the non-immune functions of hemocyte subsets in bivalves.

\subsection{Oxidative mechanisms}

The production of free radicals derived from oxygen and nitrogen in vertebrate cells was described half a century ago (Commoner et al., 1954). Reactive oxygen species (ROS) generation is generally described as a cascade of enzymatic reactions that starts with the production of the superoxide anion (O2 -) by NADPH oxidase (NOX) complexes (Fig. 8) (Dröge, 2002; Bedard and Krause, 2007; Segal, 2008). Hydrogen peroxide (H2O2) may then be produced from superoxide either spontaneously or catalysed by the superoxide dismutase (SOD) enzyme. In the presence of reduced transition metals, hydrogen peroxide can be converted into the highly-reactive hydroxyl radical $(\cdot \mathrm{OH})$. Hydrogen peroxide may also give rise to highly toxic hypochloride $(\mathrm{HOCl})$, catalysed by myeloperoxidase (MPO) in the presence of chloride ion. Reactive nitrogen species (RNS) production is catalysed by the enzyme NO synthase (NOS) and starts with the production of the NO radical (NO•), which may then be converted to various other RNS such as nitrosonium cation (NO+), nitroxyl anion (NO-) or peroxynitrite (ONOO-) (Dröge, 2002). Involvement of ROS in immune response was first characterized in the vertebrate polymorphonuclear leukocytes (PMN) (Babior et al., 1973; Klebanoff, 1975). Ingestion of foreign material through phagocytosis by PMN triggers 02 uptake and induces very rapid and strong production of ROS catalysed by NOX complexes and called "oxidative burst" (For reviews, refer to Bedard and Krause, 2007; Nauseef, 2008; Segal, 2008). Hemocytes from many bivalve species are known to be able to produce ROS. Oxidative mechanisms were reported in the oysters C. virginica, C. gigas, C. ariakensis and O. edulis (Larson et al., 1989; Bachère et al., 1991; Hégaret et al., 2003b; Lambert et al., 2003; Goedken and DeGuise, 2004; Labreuche et al., 2006; Donaghy et al., 2009), the mussels M. edulis and M. galloprovincialis (Pipe, 1992; Carballal et al., 1997b; Ordás et al., 2000b) and the scallops P. maximus and C. farreri (Le Gall et al., 1991; Chen et al., 2007a,b). In clams, few data are currently available and contradictory results between species were reported. No oxidative mechanism was described by López et al. (1994) in the carpet shell clam $R$. decussatus, using two different methods, luminol-dependent chemiluminescence (CL) and the reduction of nitroblue tetrazolium (NBT) to formazan by superoxide anion. Three years later, the occurrence of NOX activity was not detected in the hemocytes of $R$. decussatus (López et al., 1997b). The absence of ROS production mechanism in $R$. decussatus was confirmed in 2000 and 2008, using NBT technique and luminol-dependent CL, respectively (Arumugan et al., 2000; Mar Costa et al., 2008). Contrastingly, superoxide anion production was detected in both granulocytes and hyalinocytes of $R$. philippinarum, using the NBT reduction method (Cima et al., 2000). ROS production in the Manila clam was since confirmed by the use of flow cytometry and 2',7'- dichlorofluorescin-diacetate (DCFH-DA), a fluorescent indicator of $\mathrm{H} 2 \mathrm{O} 2$ and •OH production (Delaporte et al., 2003; Hégaret et al., 2007; da Silva et al., 2008). The case of $R$. decussatus may be isolated because oxidative mechanisms were also reported in other clam species such as the Pacific razor clam, Siliqua patula (Greger et al., 1995) and the hard clam M. mercenaria (Buggé et al., 2007) using lucigenin dependent $\mathrm{CL}$ and DCFH-DA, respectively. It may also be argued, however, that ROS production should exist in $R$. decussatus but has not yet been detected. Indeed, successful detection of ROS production in clam species was dependent upon the method used. For instance, in the Pacific razor clam, Greger et al. (1995) detected ROS production with lucigenin-dependent CL but not with luminol-dependent CL. In 1976, Cheng (Cheng, 1976) used measurements of oxygen consumption, biochemical assays, reduction of NBT, and detection of MPO, but detected no oxidative mechanism in M. mercenaria hemocytes. Anderson (1994), also reported an apparent lack of oxidative activity in M. mercenaria hemocytes using NBT reduction and luminal dependent CL. In 2003, however, the same authors (Anderson et al., 2003) examined again hemocyte production of ROS using another detection method, lucigenin-dependent CL. In this study, the authors finally succeeded in showing that hemocytes of $M$. mercenaria were able to generate basal ROS activity, which was further confirmed by flow-cytometric study (Buggé et al., 2007). In vertebrates, phagocytosis of foreign material or chemical stimulation was shown to induce an increase in ROS production (Bedard and Krause, 2007; Nauseef, 2008; Segal, 2008). In bivalve species, phagocytosis of zymosan particles increased oxidative mechanisms in the oysters C. gigas (Lambert et al., 2003, 2007a), C. virginica (Hégaret et al., 2003b), O. edulis (Bachère et al., 1991), the clam species S. patula (Greger et al., 1995), M. mercenaria (Buggé et al., 2007), as well as in the pectinid P. maximus (Le Gall et al., 1991). Activation with chemicals such as phorbol myristate acetate (PMA) also increased ROS production in C. virginica (Goedken and DeGuise, 2004) 
whereas, PMA exposure resulted in a decrease in ROS in C. gigas hemocytes (Lambert et al., 2003). Exposure of hemocytes to extracellular products (ECP) from a pathogenic Vibrio aestuarianus strain was shown to increase ROS production in hemocytes of $C$. gigas (Labreuche et al., 2006) and $M$. mercenaria (Buggé et al., 2007). Contrastingly, no increase in production of ROS could be detected in the Manila clam following zymosan phagocytosis, or $V$. aestuarianus ECP and PMA exposures, when measured by flow cytometry using DCFH-DA as a fluorescent probe (Lambert et al., 2005; Rifi, 2005). In human and vertebrate immunological responses, phagocytosis or chemically-induced ROS production was named "oxidative burst", based on very high intensity and short reaction time (Toreilles et al., 1996). This expression seemed to have been over-used to characterise the increase of ROS production in bivalves. Although the "burst" occurs in a few minutes in vertebrate phagocytic cells, it appears that the peak happens between 15 and $40 \mathrm{~min}$ after addition of zymosan particles for oysters C. gigas (Toreilles et al., 1996; Lambert et al., 2003), between 20 and 30min for C. virginica according to Larson et al. (1989) and 40 to $45 \mathrm{~min}$ in the scallop P. maximus (Le Gall et al., 1991; Lambert and Nicolas, 1998). Using flow cytometry and the DCFH-DA probe, recent studies also reported a peak occurring between 30 and 60min in C. virginica (Hégaret et al., 2003b) and around 70min in M. mercenaria (Buggé et al., 2007). This highly-delayed reaction time should, on its own, convince us to not use the "burst" word to characterize this phenomenon in bivalves. Furthermore, ROS production sometimes increased about 1000 to 1500 times in vertebrates (Toreilles et al., 1996); whereas, the increase was mostly confined between 2 and 10 times in bivalves (Lambert et al., 2003, 2007a; Labreuche et al., 2006; Buggé et al., 2007). Thus, the expression "oxidative burst" should be avoided to describe the increased ROS production in the hemocytes of bivalve species.

More than a terminological discrepancy, the question might be asked whether or not ROS production in bivalves can really be compared with the oxidative burst in vertebrate phagocytic cells, in terms of mechanisms and purposes. Currently, no direct link has been proven in bivalves between phagocytosis of foreign material, its degradation, and ROS production. As described above, phagocytosis of zymosan particles induced an increase in oxidative mechanisms in some species. In contrast, such an increase was not observed with phagocytosis of the protozoan parasite P. marinus by $C$. virginica hemocytes (Volety and Chu, 1995), the ingestion of a thraustochytrid protist by $M$. mercenaria hemocytes (Anderson et al., 2003), or phagocytosis of $V$. tapetis bacteria in $R$. philippinarum (Choquet, 2004; Lambert et al., 2005; Rifi, 2005), and Bacillus megaterium and Pseudomonas fluorescens bacteria in C. virginica (Bramble and Anderson, 1999). Furthermore, Bramble and Anderson (1999) reported that the inhibition of ROS production did not affect the killing of $B$. megaterium and reduced bactericidal activity towards $P$. fluorescens by only $4 \%$. Such results suggest that ROS production in hemocytes of bivalve species, at least partially, might not be directly linked with cytotoxic activity against ingested foreign organisms. This does not, however, diminish the probable importance of oxidative mechanisms in physiological processes of hemocytes in bivalves. For instance, ROS production was shown to be involved in the induction of apoptotic mechanisms in the hemocytes of $\boldsymbol{C}$. gigas (Terahara and Takahashi, 2008). Furthermore, in vertebrate cells, free radicals are also involved in various physiological processes such as cell signalling, gene expression, regulation of cell growth, reduction of metal ions, and regulation of matrix metalloproteinases or angiogenesis (for reviews, see Dröge, 2002; Bedard and Krause, 2007). In human PMN, the NADPH oxidase complex involved in ROS production during the oxidative burst was called NOX2. Since 1999, the diversity of isoforms within the NOX family has been increasing with discoveries of members from NOX1 to NOX5 and DUOX1 and 2 (Bedard and Krause, 2007). These members were characterised by ultrastructural differences and various activation processes, and different isoforms might be involved in different, as yet not fully characterized physiological processes (Bedard and Krause, 2007; Nauseef, 2008; Segal, 2008). The NOX member(s) expressed in bivalve hemocytes might not be related to NOX2. Indeed, PMA is an activator of intracellular C kinase protein (Li et al., 2000) which catalyses the phosphorylation of cytosolic proteins of NOX2 (Toreilles et al., 1996), allowing them to migrate and activate the protein complex. In some bivalve species, however, PMA stimulation did not induce an increase in ROS production. In contrast, the addition of this compound even resulted in decreased oxidative activity in C. gigas (Lambert et al., 2003, 2007a) and in the Manila clam (Lambert et al., 2005; Rifi, 2005), supporting the hypothesis of a bivalve NOX different than NOX2 expressed in bivalve hemocytes. In vertebrates, some members of the NOX family, such as NOX3 and NOX4, do not require cytosolic subunits for them to be active. Such ultrastructural organisation of the NOX member expressed in bivalves could explain the non-stimulation of PMA in hemocytes. Similarly, hemocytes in bivalves were shown to spontaneously express basal levels of ROS without the need for exogenous stimulation (Fisher et al., 2000; Anderson et al., 2003; Lambert et al., 2003, 2007a; Goedken and DeGuise, 2004). This production of ROS in the absence of phagocytosis or chemical stimulation was suggested to be induced by handling of the hemocytes and contact with non-self 
material during bleeding and storage (Lambert et al., 2007a). Spontaneous oxidative activity might also be related to structural characteristics of the NOX. Indeed, in the absence of cytosolic subunits, NOX4 can be constitutively active without the need for cell stimulation (Bedard and Krause, 2007). Once again, care has to be taken with knowledge and techniques derived from vertebrate biology. Although strong divergences were observed compared to vertebrate ROS production during phagocytosis, oxidative activity in bivalves is still considered as one of the main mechanisms involved in bivalve immune response against invading pathogens. Evidence now suggests a re-evaluation of the role of ROS production in the cellular mechanisms of hemocytes, in a larger context than immune response. Finally, mitochondrial production of ROS is currently studied in human biology for its biomedical relevance (for review of mitochondrial ROS production in mammalian, refer to Murphy, 2009). The mitochondrial ROS origin should therefore also be taken into account in bivalves, and further studies are suggested in this field.

\section{Hemocytes and environmental parameters}

Environmental factors including temperature, salinity, nutrients, and toxicants affect the health of marine bivalves. Cellular defence related parameters were suggested to be especially sensitive to variations of these factors and to reflect the physiological and health status of bivalves (Chu, 2000). Although field surveys reported that environmental variations induce modifications in hemocytes variables, interpretation of such changes is often very difficult (Flye-Sainte-Marie et al., 2009). Furthermore, laboratory-controlled conditions did not always induce obvious outcomes in hemocyte parameters. At least three hypothesis can be raised to explain the inconsistency of effects of environmental parameters on the hemocytes: (i) hemocyte parameters measured, methods used, and/or experimental timing might not be the most relevant; (ii) very high inter-individual variation might hide potential effects, not allowing demonstration of statistically-significant contrasts; and (iii) hemocytes might not be the most sensitive cells to environmental variations, as hemocytes are supposed to maintain homeostasis and integrity of bivalves. Temperature and salinity have usually been the environmental factors influencing hemocyte parameters in marine bivalves that are most studied. In laboratory experiments, temperature and salinity were shown to influence immune status of clams. In $R$. philippinarum, low water temperature and salinity induced a decrease in the concentration of hemocytes, lysozyme activity, and phagocytosis capacity (Reid et al., 2003; Paillard et al., 2004b). Several other laboratory experiments underscored the effects of temperature and salinity on hemocyte parameters in various bivalve species (Chu and La Peyre, 1993b; Fisher et al., 1996; Chu, 1998; Allamet al., 2002; Liu et al., 2004; Matozzo et al., 2007;Monari et al., 2007). Only few studies, however, have reported the impact of temperature and salinity on hemocyte parameters in the field (Fisher et al., 1996; Carballal et al., 1998; Matozzo et al., 2003; Soudant et al., 2004). Very recently, multiparametric analyses of field-recorded data reported by Flye-Sainte-Marie et al. (2009) reported temperature as the main environmental factor modulating hemocyte parameters such as granulocyte count and, subsequently, total hemocyte count (THC). As discussed above, field studies reported by Soudant et al. (2004) and Flye-Sainte-Marie et al. (2009) demonstrated seasonal effects on THC and hemocyte size. High values of THC were observed in spring- summer and low values in autumn-winter. In contrast, hemocyte size was high in autumn-winter and low in spring-summer. Thus, large hemocyte size was related to low THC, a relationship that the authors attributed to variation in hemocyte cell-division rate. Indeed, when cell division occurred, the size of resulting cells was speculated to be smaller than the size of mature cells. This might be an example of the highlyadaptive nature of hemocytes to altered environmental conditions. Autumn and winter seasons are characterized by low temperature and low food availability, dramatically reducing activities and energy availability for the clams, respectively. Two nonexclusive hypotheses might explain the decrease in THC during winter: (i) cell division requires large energy and material inputs, and should be reduced to preserve accumulated reserves; (ii) the decrease in hemocyte concentration in hemolymph might result from reduced nutritional activities (reflecting both less food availability and lower temperature) in winter, as hemocytes are thought to be involved in digestion and nutrient transport. Food quality also influenced both biochemical composition of hemocytes and immune parameters of bivalves. Delaporte et al. (2003) evaluated the impact of three diets (Chaetoceros calcitrans, T-Isochrysis and Tetraselmis suecica) upon the fatty-acid composition of hemocyte membrane lipids and upon immune parameters of the Manila clam. Concentration of hemocytes, percentage of granulocytes, phagocytic activity and ROS production were influenced by diets. These changes were speculated to be related to fatty-acid composition modifications of $R$. philippinarum hemocytes resulting from diets. In the oyster $C$. gigas, arachidonic-acid supplementation induced an increase in hemocyte concentration, phagocytosis, and ROS production (Delaporte et al., 2006); whereas, eicosapentanoicacid supplementation resulted in a decrease in phagocytosis and ROS production (Delaporte et al., 2007b). The diet of clams is mainly 
composed of microalgae. Some dinoflagellate and diatom species, however, produce biotoxins of various kinds (Hallegraeff, 1993; Smayda, 1997a,b). By ingesting such microalgal species, clams are exposed to a variety of toxic components. This kind of global phenomenon, called harmful-algal blooms (HABs), may cause pathologies and mortalities in the shellfish themselves (Shumway, 1990; Landsberg, 2002). Hemocyte parameters were thought to reflect the health status of the clams and to be used as biomarkers of the toxic effects of microalgal species. Hemocytes might not be the mostexposed or sensitive cells to such toxins though. The impacts of two dinoflagellate species (Karenia selliformis and Karenia mikimotoi) were demonstrated with sub-lethal, pathological effects upon the clam R. philippinarum (Hégaret et al., 2007; da Silva et al., 2008). After exposure for 3 and 6 days to both toxic dinoflagellates, and for 6 weeks to $K$. selliformis, THC increased in exposed clams and a decrease in percentage of apoptotic cells, as well as hemocyte size and complexity, were reported. These authors suggested that the small size and complexity of the hemocytes resulted from a toxin effect. The increase in THC, however, may have been a result of a cell proliferation process and, as the authors said, "these hemocytes are possibly 'young' cells less prone to mortality, decreasing the percentage of dead hemocytes in the hemocyte population". The observed decrease in size and complexity might also result from this proliferation. Alternately, the observed variation might be indirectly induced. Toxins may alter physiological status of digestive cells and other tissues, inducing the multiplication of circulating hemocytes to repair and protect the whole organism. Very recently, Ford et al. (2008) investigated the effects of Alexandrium tamarense, another dinoflagellate species producing paralytic shellfish toxin (PST), on hemocyte parameters of $R$. philippinarum. Isolated hemocyteswere exposed in vitro to extracts of one highly-toxic, PST-producing strain and one nonPST-producing strain of $A$. tamarense. No measurable effect was observed from PST-producing strain on hemocytes. In contrast, an extract from the non-PST-producing strain seemed to provoke negative effects on hemocytes, resulting in lower adherence and phagocytic activities. Accordingly, definition of toxic and non-toxic algae, based upon knowledge and standards from vertebrate studies should not be satisfactory to characterize toxicity of algae species on bivalves. Furthermore, direct contact between hemocytes and toxins might sometimes not be necessary for effects, depending upon the toxin and the capacity of algal species to release it. In this way, in vivo experiments might allow a better simulation of physiological reality without the elimination of steps potentially important in understanding toxic algae effects. Development of in vitro tests with isolated hemocytes, however, represents an easy and rapid way to measure toxicity of microalgal species. Finally, nothing is known about detoxification process in hemocyte populations and their capacities to internalize, inactivate, and eliminate toxins. Environmental conditions experienced by bivalves may also be altered by anthropogenic activities. Heavy metals released into aquatic system have been paid great attention because of a high threat for human health. Monitoring and prevention of heavy-metal pollution is an enduring topic in environmental research (for review see Zhou et al., 2008). Bivalves are known to accumulate metals and are commonly used for biomonitoring of aquatic metal pollution. Assessment of aquatic heavy-metal presence can be monitored by various techniques, such as determination of the contents of heavy metals, measurements of enzyme activities, or histopathological observations. It has been shown that hemocytes of bivalves are able to accumulate high amounts of metals, which may have detrimental consequences on the physiological and immune parameters of hemocytes. The literature, however, provides clues that the fate of heavy metals and induction of deleterious effects in hemocytes differ depending upon both metal and concentration. Furthermore, Fisher (2004a) suggested that all heavy metals might not be harmful for bivalves and that "the perception of harm originates from the knowledge that such high concentrations would be quite toxic to most other biota". First, all heavy metals are not similarly accumulated and detoxified in clams. The Manila clam was shown to accumulate silver (Ag) and cadmium (Cd) over time but not zinc (Zn) (Ng and Wang, 2004). Although the carpet shell clam accumulated $\mathrm{Cd}$ and copper $(\mathrm{Cu})$, Cd content remained stable after a detoxification period of 8 days; whereas, Cu concentration rapidly decreased (Gnassia-Barelli et al., 1995). Secondly, effects on hemocyte parameters varied with the nature and concentration of heavy metals. Matozzo et al. (2001) investigated the response of hemocytes of $R$. philippinarum to in vivo $\mathrm{Cu}$ and $\mathrm{Cd}$ exposure. These authors showed that lysosomal alteration was enhanced by high concentrations of both metals, but hemocytes from clams exposed to $\mathrm{Cu}$ showed a significant decrease in phagocytic activity; whereas, no inhibition was observed in cells from Cd-exposed animals. In the same way, exposure to $\mathrm{Cu}$ but not $\mathrm{Cd}$ also caused a significant reduction in hemocyte superoxide dismutase, suggesting higher toxicity of $\mathrm{Cu}$ than $\mathrm{Cd}$ in clams. In contrast, accumulation of heavy metals in hemocytes for physiological purposes was demonstrated in eastern oyster, $C$. virginica, hemocytes, in which $\mathrm{Cu}$ and $\mathrm{Zn}$ might be accumulated for antimicrobial activities (Fisher, 2004a) and various metals might be involved in shell structure and formation (Fisher, 2004b). Thus, although accumulation of some heavy metals in bivalves might lead to sub-lethal, deleterious 
physiological effects, distinctions have to be made between hemocyte reactions and whole animal response, and between the different kinds of metals. Although in situ and laboratory-controlled environmental parameters influence hemocyte characteristics in clams, such variations are often inconsistent with no strong correlations between individual environmental conditions and hemocyte parameters, leading to problematic interpretations (Flye-Sainte-Marie et al., 2009). Some studies, nevertheless, have succeeded in demonstrating the impact of environmental factors on hemocyte parameters, suggesting these as potential biomarkers of the physiological status of clams. Actually, environmental modification may lead to two main forms of response, either long-term or transitory modification of hemocyte variables. Short-term responses could explain the difficulties in analyzing and interpreting data, which then depend upon experimental timing. Concerning long-term responses, one of the commonly-raised questions is whether or not resulting hemocyte variations might increase the sensitivity of bivalves to another stress, such as infections or pollutants. In fact, only a few studies demonstrated a link between environment and bivalve health through modifications of hemocyte variables. For instance, Pipe and Coles (1995) reported that the incubation of mussels with copper induced modifications in hemocyte variables, leading to increased susceptibility to $V$. tubiashii infection. Hemocytes of $R$. philippinarum were affected by a salinity decrease, leading to higher sensitivity of the clams to brown ring disease induced by $V$. tapetis (Reid et al., 2003). Finally, recently, Gagnaire et al. (2007) showed that exposure of $C$. gigas to pesticides increased oyster sensitivity to bacterial challenge (Vibrio splendidus-like strains) through modifications of hemocyte variables. Finally, to reach higher sensitivity and specificity of the hemocytes as biomarkers, it might be essential to concomitantly measure other physiological parameters because some observed effects on hemocytes might be indirect and mediated by other impacted organs. Further field studies and development of various bioassays have to be performed to improve understanding of the complex relationships between environment, hemocytes, and bivalve physiology.

\section{Conclusion}

Current knowledge of biology and physiology of hemocytes in clams and, more generally in bivalves, ismostly focussed on their involvement in immune response. This restriction might have arisen fromat least two main reasons: (i) scientific researches were first conducted on hemocytes in fishery and aquaculture contexts. Indeed, mass mortalities of commercially-important bivalves were possibly linked with infectious diseases. It was thus important to understand immune responses of bivalves; (ii) hemocytes were promptly compared with vertebrate immune cells. Undeniably, both kinds of cells circulate in hemolymph/ blood, are involved in immune response, and exhibit some functional similarities. Hemocyteswere then sometimes observed through the lens of vertebrate and human immunology. Similar immune techniques were developed and some phenomena were sometimes extrapolated or anticipated from vertebrate immune principles. The time may have come, however, to break from the vertebrate context. Further comparisons might be artificial and lead to misinterpretations. In this way, some studies with marine invertebrates have already started to shake dogmas based upon vertebrate criteria. For instance, it was commonly assumed that bivalves only developed innate immunity. Such a dogma was based upon the absence of antigen-specific lymphocytes and immunoglobulins in invertebrates. Recent studies, however, have described a sort of immune-specific memory in some invertebrates (For review, see Rowley and Powell, 2007). Self recognition receptors were identified in the ascidium Botryllus schlosseri (Nyholm et al., 2006), and vaccines were developed in shrimp limiting susceptibility to the White Spot Syndrome Virus (Witteveldt et al., 2004, 2006; Rajesh Kumar et al., 2008) and to the bacterium Vibrio harveyi (Alabi et al., 1999). The biology of hemocytes in bivalves is complex and not limited to immunity. Future investigations should widen study fields to improve understanding of the specific functions of various hemocyte subsets in the systemic physiology of bivalves and to discover the astonishing and wide capacities of hemocytes.

\section{Acknowledgements}

This work is part of a post Graduate education project for subtropical marine life science, supported by Brain Korea 21 (BK21) Project Grant of Ministry of Education, Science and Technology. Sincere thanks are due to Gary H. Wikfors for the English corrections. 


\section{References}

Alabi, A.O., Jones, D.A., Latchford, J.W., 1999. The efficacy of immersion as opposed to oral vaccination of Penaeus indicus larvae against Vibrio harveyi. Aquaculture 178, 1-11.

Aladaileh, S., Nair, S.V., Birch, D., Raftos, D.A., 2007. Sydney rock oyster (Saccostrea glomerata) hemocytes: morphology and function. J. Invertebr. Pathol. 96, 48-63.

Allam, B., Paillard, C., 1998. Defense factors in clam extrapallial fluids. Dis. Aquat. Org. 33, 123-128.

Allam, B., Paillard, C., Auffret, M., 2000. Alterations in hemolymph and extrapallial fluid parameters in theManila clam, Ruditapes philippinarum, challengedwith the pathogen Vibrio tapetis. J. Invertebr. Pathol. 76, 63-69.

Allam, B., Ashton-Alcox, K.A., Ford, S.E., 2002. Flow cytometric measurement of hemocyte viability and phagocytic activity in the clam, Ruditapes philippinarum. J. Shellfish Res. 21, 13-19.

Anderson, R.S., 1994. Hemocyte-derived reactive oxygen intermediate production in four bivalve mollusks. Dev. Comp. Immunol. 18, 89-96.

Anderson, R.S., Kraus, B.S., McGladderyn, S.E., Reece, K.S., Stokes, N.A., 2003. A thraustochytrid protist isolated from Mercenaria mercenaria: molecular characterization and host defense responses. Fish Shellfish Immunol. 15, 183-194.

Arumugan, M., Romestand, B., Torreilles, J., 2000. Nitrite released in haemocytes from Mytilus galloprovincialis, Crassostrea gigas and Ruditapes decussatus upon stimulation with phorbol myristate acetate. Aquat. Living Resour. 13, 173-177.

Ashton-Alcox, K.A., Ford, S.E., 1998. Variability in molluscan hemocytes: a flow cytometric study. Tissue Cell 30, $195-204$.

Auffret, M., 1985. "Morphologie comparative des types hémocytaires chez quelques mollusques bivalves d'intérêt commercial.". $\mathrm{PhD}$ Thesis, University of Bretagne Occidentale, Brest, France. In French.

Auffret, M., 1988. Bivalve hemocyte morphology. Am. Fish. Soc. Spec. Pub. 18, 169-177.

Babior, B.M., Kipnes, R.S., Curnutte, J.T., 1973. Biological defence mechanisms: the production by leukocytes of superoxide, a potential bactericidal agent. J. Clin. Invest. 52, 741-744.

Bachère, E., Hervio, D., Mialhe, E., 1991. Luminol-dependent chemiluminescence by haemocytes of two marine bivalves, Ostrea edulis and Crassostrea gigas. Dis. Aquat. Org. 11, 173-180.

Bachère, E., Mialhe, E., Noël, D., Boulo, V., Morvan, A., Rodriguez, J., 1995. Knowledge and research prospects in marine mollusc and crustacean immunology. Aquaculture 132, 17-32.

Bedard, K., Krause, K.H., 2007. The NOX family of ROS-generating NADPH oxidases: physiology and pathophysiology. Physiol. Rev. 87, 245-313.

Beninger, P.G., Le Pennec, G., Le Pennec, M., 2003. Demonstration of nutrient pathway from the digestive system to oocytes in the gonad intestinal loop of the scallop Pecten maximus L. Biol. Bull. 205, 83-92.

Bigas, M., Durfort, M., Poquet, M., 2006. Cytological response of hemocytes in the European flat oyster, Ostrea edulis, experimentally exposed to mercury. BioMetals 19, 659-673.

Blasius, A.L., Barchet, W., Cella, M., Colonna, M., 2008. Development and function of murine B220+CD11C+NK1.1+ cells identify them as a subset of NK. J. Exp. Med. 204, 2561-2568.

Borsa, P., Thiriot-Quiévreux, C., 1990. Karyological and allozymic characterization of Ruditapes philippinarum, R. aureus and $R$. decussatus (Bivalvia, Veneridae). Aquaculture 90, 209-227.

Bower, S.M., McGladdery, S.E., 2003. Synopsis of infectious diseases and parasites of commercially exploited shellfish. http://www-sci.pac.dfo-mpo.gc.ca/shelldis/ title_e.htm.

Bramble, L.H., Anderson, R.S., 1999. Lack of involvement of reactive oxygen species in the bactericidal activity of Crassostrea virginica haemocytes in contrast to Morone saxatilis phagocytes. Fish Shellfish Immunol. 9, 109-123.

Buggé, M.D., Hégaret, H., Wikfors, G.H., Allam, B., 2007. Oxidative burst in hard clam (Mercenaria mercenaria) haemocytes. Fish Shellfish Immunol. 23, 188-196.

Bulgakov, A.A., Park, K.I., Choi, K.S., Lim, H.K., Cho, M., 2004. Purification and characterisation of a lectin isolated from the manila clam Ruditapes philippinarum in Korea. Fish Shellfish Immunol. 16, 487-499.

Cajaraville,M.P., Pal, S.G., 1995. Morphofunctional study of the haemocytes of the bivalve mollusc Mytilus galloprovincialis with emphasis on the endolysosomal compartment. Cell Struct. Funct. 20, 355-367.

Caminschi, I., Ahmet, F., Heger, K., Brady, J., Nutt, S.L., Vremec, D., Pietersz, S., Lahoud,M.H., Schofield, L., Hansen, D.S., O'Keeffe, M., Smyth, M.J., Bedoui, S., Davey, G.M., Villadangos, J.A., Heath, W.R., Shortman, K., 2008. Putative IKDCs are functionally and developmentally similar to natural killer cells, but not to dendritic cells. J. Exp. Med. 204, 2579-2590.

Canesi, L., Gallo, G., Gavioloi, M., Pruzzo, C., 2002. Bacteria-hemocyte interactions and phagocytosis in marine bivalves. Microsc. Res. Tech. 57, 469-476.

Carballal, M.J., López, C., Azevedo, C., Villalba, A., 1997a. Hemolymph cell types of the mussel Mytilus galloprovincialis. Dis. Aquat. Org. 29, 127-135.

Carballal, M.J., López, C., Azevedo, C., Villalba, A., 1997b. In vitro study of phagocytic ability of Mytilus galloprovincialis Lmk. haemocytes. Fish Shellfish Immunol. 7, 403-416.

Carballal, M.J., Villalba, A., López, C., 1998. Seasonal variation and effects of age, food availability, size, gonadal development, and parasitism on the hemogram of Mytilus galloprovincialis. J. Invertebr. Pathol. 72, 304-312.

Chagot, D., Comps, M., Boulo, V., Ruano, F., Grizel, H., 1987. Histological study of a cellular reaction in Ruditapes decussatus infected by a protozoan. Aquaculture 67, 260-261.

Chan, C.W., Crafton, E., Fan, H.N., Flook, J., Yoshimura, K., Skarica, M., Brockstedt, D., Dubensky, T.W., Stins, M.F., Lanier, L.L., Pardoll, D.M., Housseau, F., 2006. Interferon producing killer dendritic cells provide a link between innate and adaptative immunity. Nat. Med. 12, 207-213. 
Chen, M.Y., Yang, H.S., Delaporte, M., Zhao, S.J., Xing, K., 2007a. Immune responses of the scallop Chlamys farreri after air exposure to different temperatures. J. Exp. Mar. Biol. Ecol. 345, 52-60.

Chen, M.Y., Yang, H.S., Delaporte, M., Zhao, S.J., 2007b. Immune condition of Chlamys farreri in response to acute temperature challenge. Aquaculture 271, 479-487.

Cheney, D.P., 1971. A summary of invertebrate leucocyte morphology with emphasis on blood element of the Manila clam, Tapes semidecussata. Biol. Bull. 140, 353-368.

Cheng, T.C., 1975. Functional morphology and biochemistry of molluscan phagocytes. Ann. N. Y. Acad. Sci. 266, 343-379.

Cheng, T.C., 1976. Aspects of substrate utilization and energy requirement during molluscan phagocytosis. J. Invertebr. Pathol. 27, 263-268.

Cheng, T.C., 1981. Bivalves. In: N.A.R.A.R. editor. Invertebrate blood cells. Acad. Press, London, UK, pp. 233-300.

Cheng, T.C., 1996. Hemocytes: forms and functions. In: Kennedy, V.S., Newell, R.I.E., Eble, A.F. (Eds.), The Eastern Oyster Crassostrea virginica. Maryland Sea Grant Book, College Park, MD, USA, pp. 299-333.

Cheng, T.C., 2000. Cellular defense mechanisms in oysters. In: Fingerman, N., Nagabhushanam, R. (Eds.), Recent advances in marine biotechnology. Immunobiology and pathology. Science Publishers, Enfield (NH), USA, pp. 43-83.

Choi, K.S., Park, K.I., Cho, M., Soudant, P., 2005. Diagnosis, pathology, and taxonomy of Perkinsus sp. isolated from the manila clam Ruditapes philippinarum in Korea. J. Aquac. 18, $207-214$.

Choquet, G., 2004. "Caractérisation et pathogénie des isolats de Vibrio tapetis, bactérie responsable de la maladie de l'anneau brun chez les palourdes". PhD Thesis, University of Bretagne Occidentale, Brest, France. In French.

Chu, F.L.E., 1988. Humoral defense factors in marine bivalves. Am. Fish. Soc. Spec. Publ. 18, 178-188.

Chu, F.L.E., 1998. Host defenses against Perkinsus marinus: a review of recent findings in the eastern oyster, Crassostrea virginica. J. Shellfish Res. 18, 321-322.

Chu, F.L.E., 2000. Defense mechanisms of marine bivalves. In: Fingerman, N., Nagabhushanam, R. (Eds.), Recent advances in marine biotechnology. Immunobiology and pathology. Science Publishers, Enfield (NH), USA, pp. 1-42.

Chu, F.L.E., La Peyre, J.F., 1989. Effect of environmental factors and parasitismon hemolymph lysozyme and protein of american oysters (Crassostrea virginica). J. Invertebr. Pathol. 54, 224-232.

Chu, F.L.E., La Peyre, J.F., 1993a. Development of disease caused by the parasite Perkinsus marinus and defense-related hemolymph factors in three populations of oysters from the Chesapeake bay, USA. J. Shellfish Res. 12, 21-27.

Chu, F.L.E., La Peyre, J.F., 1993b. Perkinsus marinus susceptibility and defense-related activities in eastern oysters Crassostrea virginica: Temperature effects. Dis. Aquat. Org. 16, 223-234.

Chu, F.L.E., La Peyre, J.F., Burreson, C.S., 1993. Perkinsus marinus infection and potential defense-related activities in eastern oysters, Crassostrea virginica: Salinity effects. J. Invertebr. Pathol. 62, 226-232.

Chu, F.L.E., Volety, A.K., La Peyre, J.F., 1995. Annual variation of hemolymph components and Perkinsus marinus infection in oysters sampled from deep water shoal, James river, Virginia. J. Shellfish Res. 14, 263.

Cima, F., Matozzo, V., Marin, M.G., Ballarin, L., 2000. Haemocytes of the clam Tapes philippinarum (Adams \& Reeve, 1850): morphofunctional characterisation. Fish Shellfish Immunol. 10, 677-693.

Commoner, B., Townsend, J., Pake, G.E., 1954. Free radicals in biological materials. Nature 174, 689-691.

da Silva, P.M., Hégaret, H., Lambert, C., Wikfors, G.H., Le Goïc, N., Shumway, S.E., Soudant, P., 2008. Immunological responses of the manila clam (Ruditapes philippinarum) with varying parasite (Perkinsus olseni) burden, during a long-term exposure to the harmful alga, Karenia selliformis, and possible interactions. Toxicon 51, 563-573.

Delaporte, M., Soudant, P., Moal, J., Lambert, C., Quéré, C., Miner, P., Choquet, G., Paillard, C., Samain, J.F., 2003. Effect of mono-specific algal diet on immune functions in two bivalve species Crassostrea gigas and Ruditapes philippinarum. J. Exp. Biol. 206, 3053-3064.

Delaporte, M., Soudant, P., Moal, J., Giudicelli, E., Lambert, C., Séguineau, C., Samain, J.F., 2006. Impact of 20:4n-6 supplementation on the fatty acid composition and hemocyte parameters of the pacific oyster Crassostrea gigas. Lipids 41, 567-576.

Delaporte, M., Soudant, P., Lambert, C., Jegaden, M., Moal, J., Pouvreau, S., Dégremont, L., Boudry, P., Samain, J.F., $2007 a$. Characterisation of physiological and immunological differences between Pacific oysters (Crassostrea gigas) genetically selected for high or low survival to summer mortalities and fed different rations under controlled conditions. J. Exp. Mar. Biol. Ecol. 353, 45-57.

Delaporte, M., Chu, F.L., Langdon, C., Moal, J., Lambert, C., Samain, J.F., Soudant, P., 2007b. Changes in biochemical and hemocyte parameters of the Pacific oysters Crassostrea gigas fed T-Iso supplemented with lipid emulsions rich in eicosapentaenoic acid. J. Exp. Mar. Biol. Ecol. 343, 261-275.

Desjardins, M., Houde, M., Gagnon, E., 2005. Phagocytosis: the convoluted way from nutrition to adaptative immunity. Immunol. Rev. 207, 158-165.

Donaghy, L., Kim, B.-K., Hong, H.-K., Park, H.-S., Choi, K.-S., 2009. Flow cytometry studies on the populations and immune parameters of the hemocytes of the Suminoe oyster, Crassostrea ariakensis. Fish Shellfish Immunol. 27, 296-301.

Dröge, W., 2002. Free radicals in the physiological control of cell function. Physiol. Rev. 82, 47-95.

Dyrynda, E.A., Pipe, R.K., Ratcliff, N.A., 1997. Sub-populations of haemocytes in the adult and developing marine mussel, Mytilus edulis, identified by use of monoclonal antibodies. Cell Tissue Res. 289, 527-536.

Fawcett, L.B., Tripp, M.R., 1994. Chemotaxis of Mercenaria mercenaria haemocytes to bacteria in vitro. J. Invertebr. Pathol. 63 , 275-284.

Fisher, W.S., 2004a. Antimicrobial activity of copper and zinc accumulated in eastern oyster amebocytes. J. Shellfish Res. 23 , 321-351.

Fisher, W.S., 2004b. Relationship of amebocytes and terrestrial elements to adult shell deposition in eastern oysters. J. Shellfish Res. 23, 353-367. 
Fisher, W.S., Newell, R.I.E., 1986. Seasonal and environmental variation in protein and carbohydrate levels in the hemolymph from American oysters (Crassostrea virginica gmelin). Comp. Biochem. Physiol. A: Mol. Integr. Physiol. 85, 365-372.

Fisher, W.S., Oliver, L.M., Edwards, P., 1996. Hematologic and serologic variability of eastern oysters from Apalachicola Bay, Florida. J. Shellfish Res. 15, 555-564.

Fisher, W.S., Oliver, L.M., Winstead, J.T., Long, E.R., 2000. A survey of oysters Crassostrea virginica from Tampa Bay, Florida: associations of internal defense measurements with contaminant burdens. Aquat. Toxicol. 51, 115-138.

Flassch, J.P., Leborgne, Y., 1992. Introduction in Europe, from 1972 to 1980, of the Japanese Manila clam (Tapes philippinarum) and effects on aquaculture production and natural settlement. ICES Mar. Sci. Symp. 194, 92-96.

Flye-Sainte-Marie, J., Pouvreau, S., Paillard, C., Jean, F., 2007. Impact of brown ring disease on the energy budget of the Manila clam Ruditapes philippinarum. J. Exp. Mar. Biol. Ecol. 349, 378-389.

Flye-Sainte-Marie, J., Soudant, P., Lambert, C., Le Goïc, N., Goncalvez, M., Travers, M.-A., Paillard, C., Jean, F., 2009. Variability of the hemocyte parameters of Ruditapes philippinarum in the field during an annual cycle. J. Exp. Mar. Biol. Ecol. 377, 1-11.

Ford, S.E., Bricelj, V.M., Lambert, C., Paillard, C., 2008. Deleterious effects of a nonPST bioactive compound(s) from Alexandrium tamarense on bivalve hemocytes. Mar. Biol. 154, 241-253.

Gagnaire, B., Gay, M., Huvet, A., Daniel, J.Y., Saulnier, D., Renault, T., 2007. Combination of a pesticide exposure and a bacterial challenge: In vivo effects on immune response of Pacific oyster, Crassostrea gigas (Thunberg). Aquat. Toxicol. 84, 92-102.

Ganz, T., 1999. Defensins and host defense. Science 286, 420-421.

Garreis, K.A., La Peyre, J.F., Faisal, M., 1996. The effects of Perkinsus marinus extracellular products and purified proteases on oyster defence parameters in vitro. Fish Shellfish Immunol. 6, 581-597.

Gérard, A., 1978. Étude des garnitures chromosomiques de deux Veneridae: Ruditapes decussatus (L.) et Ruditapes philippinarum (Adams et Reeve). Haliotis 9, 69-71 In French.

Gestal, C., Costa, M., Figueras, A., Novoa, B., 2007. Analysis of differentially expressed genes in response to bacterial stimulation in hemocytes of the carpet-shell clam Ruditapes decussatus: identification of new antimicrobial peptides. Gene 406, 134-143.

Gnassia-Barelli, M., Romeo, M., Puiseux-Dao, S., 1995. Effects of cadmium and copper contamination on calcium content of the bivalve Ruditapes decussatus. Mar. Environ. Res. 39, 325-328.

Goedken, M., DeGuise, S., 2004. Flow cytometry as a tool to quantify oyster defense mechanisms. Fish Shellfish Immunol. 16, 539-552.

Gosling, E., 2002. Bivalve Molluscs. Biology, Ecology and Culture. Fishing News Books. Blackwell Publishing, Oxford, UK.

Greger, E.A., Drum, A.S., Elston, R.A., 1995. Measurement of oxidative activity in hemocytes of the Pacific Razor Clam, Siliqua patula, and the oyster, Crassostrea gigas, using lucigenin- and luminol-dependent chemiluminescence. J. Invertebr. Pathol. 65, 48-60.

Hallegraeff, G.M., 1993. A review of harmful algal blooms and their apparent global increase. Phycologia 32, 79-99.

Hamaguchi, M., Suzuki, N., Usuki, H., Ishioka, H., 1998. Perkinsus protozoan infection in short-necked clam Tapes (=Ruditapes) philippinarum in Japan. Fish Pathol. 33, 473-480.

Harris-Young, L., Tamplin, M.L., Mason, J.W., Aldrich, H.C., Jackson, J.K., 1995. Viability of Vibrio vulnificus in association with hemocytes of the american oyster (Crassostrea virginica). Appl. Environ. Microbiol. 61, 52-57.

Hégaret, H., 2007. Impacts of harmful algal blooms on physiological and cellular processes of bivalve molluscs. PhD Thesis, Ecole Nationale Supérieure Agronomique de Rennes, France, and University of Connecticut, USA.

Hégaret, H., Wikfors, G.H., Soudant, P., 2003a. Flow-cytometric analysis of haemocytes from eastern oysters, Crassostrea virginica, subjected to a sudden temperature elevation: I. Haemocyte types and morphology. J. Exp. Mar. Biol. Ecol. 293, 237-248.

Hégaret, H., Wikfors, G.H., Soudant, P., 2003b. Flow cytometric analysis of haemocytes from eastern oysters, Crassostrea virginica, subjected to a sudden temperature elevation: II. Haemocyte functions: aggregation, viability, phagocytosis, and respiratory burst. J. Exp. Mar. Biol. Ecol. 293, 249-265.

Hégaret, H., da Silva, P.M., Wikfors, G.H., Lambert, C., De Bettignies, T., Shumway, S.E., Soudant, P., 2007. Hemocyte responses of manila clams, Ruditapes philippinarum, with varying parasite, Perkinsus olseni, severity to toxic-algal exposures. Aquat. Toxicol. 84, 469-479.

Hégaret, H., da Silva, P.M., Sunila, I., Shumway, S.E., Dixon, S., Alix, J., Wikfors, G.H., Soudant, P., 2009. Perkinsosis in the Manila clam Ruditapes philippinarum affects responses to the harmful-alga, Prorocentrum minimum. J. Exp. Mar. Biol. Ecol. 371, 112-120.

Hine, P.M., 1999. The inter-relationships of bivalve haemocytes. Fish Shellfish Immunol. 9, 367-385.

Itoh, N., Xue, Q., Li, Y., Cooper, R.K., La Peyre, J.F., 2007. cDNA cloning and tissue expression of plasma lysozyme in the eastern oyster, Crassostrea virginica. Fish Shellfish Immunol. 23, 957-968.

Kang, Y.S., Kim, Y.M., Park, K.I., KimCho, S., Choi, K.S., Cho, M., 2006. Analysis of EST and lectin expressions in hemocytes of manila clams (Ruditapes philippinarum) (bivalvia: Mollusca) infected with Perkinsus olseni. Dev. Comp. Immunol. 30, 1119-1131.

Kim, Y.M., Park, K.I., Choi, K.S., Alvarez, R.A., Cummings, R.D., Cho, M., 2006. Lectin from the manila clam Ruditapes philippinarum is induced upon infection with the protozoan parasite Perkinsus olseni. J. Biol. Chem. 281, 2685426864.

Kim, J.Y., Adhya,M., Cho, S.K., Choi, K.S., Cho,M., 2008a. Characterization, tissue expression, and immunohistochemical localization of $\mathrm{mcl} 3$, a c-type lectin produced by Perkinsus olseni-infected manila clams (Ruditapes philippinarum). Fish Shellfish Immunol. 25, 598-603. 
Kim, J.Y., Kim, Y.M., Cho, S.K., Choi, K.S., Cho, M., 2008b. Noble tandem-repeat galectin of manila clam Ruditapes philippinarum is induced upon infection with the protozoan parasite Perkinsus olseni. Dev. Comp. Immunol. 32, 11311141 .

Klebanoff, S.J., 1975. Antimicrobial mechanisms in neutrophilic polymorphonuclear leukocytes. Semin. Hematol. 12, 117-142.

La Peyre, J.F., Chu, F.L.E., Meyers, J.M., 1995. Haemocytic and humoral activities of eastern and pacific oysters following challenge by the protozoan Perkinsus marinus. Fish Shellfish Immunol. 5, 179-190.

Labreuche, Y., Soudant, P., Goncalves, M., Lambert, C., Nicolas, J.L., 2006. Effects of extracellular products from pathogenic Vibrio aestuarianus strain 01/32 on lethality and cellular immune responses of the oyster Crassostrea gigas. Dev. Comp. Immunol. 30, 367-379.

Lambert, C., Nicolas, J.L., 1998. Specific inhibition of chemiluminescent activity by pathogenic Vibrios in hemocytes of two marine bivalves: Pecten maximus and Crassostrea gigas. J. Invertebr. Pathol. 71, 53-63.

Lambert, C., Soudant, P., Choquet, G., Paillard, C., 2003. Measurement of Crassostrea gigas haemocyte oxidative metabolism by flow cytometry and the inhibiting capacity of pathogenic vibrios. Fish Shellfish Immunol. 15, 225-240.

Lambert, C., Soudant, P., Jegaden, M., Labreuche, Y., Rifi, M., Moal, J., 2005. Modulation of Reactive Oxygen Species (ROS) production by hemocyte of two aquacultured bivalves, clam and oyster, faced to pathogenic Vibrio. In: Moal, J., Soudant, P., Volety, A.K. (Eds.), Book of abstract : 8th International Conference on Shellfish Restoration, Brest, France, p. 60. abstract only.

Lambert, C., Soudant, P., Jegaden, M., Delaporte, M., Labreuche, Y., Moal, J., Samain, J.F., 2007a. In vitro modulation of reactive oxygen and nitrogen intermediate $(\mathrm{ROI} / \mathrm{RNI})$ production in Crassostrea gigas hemocytes. Aquaculture 270 , 413-421.

Lambert, C., Soudant, P., Dégremont, L., Delaporte, M., Moal, J., Boudry, P., Jean, F., Huvet, A., Samain, J.F., 2007b. Hemocyte characteristics in families of oysters, Crassostrea gigas, selected for differential survival during summer and reared in three sites. Aquaculture 270, 276-288.

Landsberg, J.H., 2002. The effects of harmful algal blooms on aquatic organisms. Rev. Fish. Sci. 10, 113-390.

Langdon, C.J., Newell, R.I.E., 1990. Utilization of detritus and bacteria as food sources by 2 bivalve suspension-feeders, the oyster Crassostrea virginica and the mussel Geukensia demissa. Mar. Ecol., Prog. Ser. 58, $299-310$.

Larson, K.G., Robertson, B.S., Hetrick, F.M., 1989. Effect of environmental pollutants on the chemiluminescence of haemocytes from the American oyster Crassostrea virginica. Dis. Aquat. Org. 6, 131-136.

Le Gall, G., Bachère, E., Mialhe, E., 1991. Chemiluminescence analysis of the activity of Pecten maximus haemocyte stimulated with zymosan and host-specific rickettsiales- like organisms. Dis. Aquat. Org. 11, 181-186.

Lee, M.K., Cho, B.Y., Lee, S.J., Kang, J.Y., Jeong, H.D., Huh, S.H., Huh, M.D., 2001. Histopathological lesions of manila clam, Tapes philippinarum, from Hadong and Namhae coastal areas of Korea. Aquaculture 201, 199-209.

Lewis,K.E.,O'Day,D.H., 2007. Phagocytosis in Dictyostelium: nibbling, eating and cannibalism. J. Eukaryot. Microbiol. 43, 65-69.

Li, H., Hu, J., Xin, W., Zhao, B., 2000. Production and interaction of oxygen and nitric oxide free radicals in PMA stimulated macrophages during the respiratory burst. Redox Rep. 5, 353-358.

Liang, Y.B., Zhang, X.C., Wang, L.J., Yang, B., Zhang, Y., Cai, C.L., 2001. Prevalence of Perkinsus sp. in the Manila clam, Ruditapes philippinarum, along the northern coast of the Yellow Sea in China. Oceanol. Limnol. Sin. 32, $502-511$.

Liu, S., Jiang, X., Hu, X., Gong, J., Hwang, H., Mai, K., 2004. Effects of temperature on non-specific immune parameters in two scallop species: Argopecten irradians (Lamarck 1819) and Chlamys farreri (Jones \& Preston 1904). Aquac. Res. 35, 678-682.

López, C., Villalba, A., Bachère, E., 1994. Absence of generation of active oxygen radicals coupled with phagocytosis by the hemocytes of the clam, Ruditapes decussatus (mollusca: Bivalvia). J. Invertebr. Pathol. 64, 188-192.

López, C., Carballal, M.J., Azevedo, C., Villalba, A., 1997a. Morphological characterization of the hemocytes of the clam, Ruditapes decussatus (mollusca: Bivalvia). J. Invertebr. Pathol. 69, 51-57.

López, C., Carballal, M.J., Azevedo, C., Villalba, A., 1997b. Enzyme characterisation of the circulating haemocytes of the carpet shell clam Ruditapes decussatus (Mollusca: bivalvia). Fish Shellfish Immunol. 7, 595-608.

López, C., Carballal, M.J., Azevedo, C., Villalba, A., 1997c. Differential phagocytic ability of the circulating haemocyte types of the carpet shell clam Ruditapes decussatus (Mollusca: Bivalvia). Dis. Aquat. Org. 30, 209-215.

Lopez-Cortes, L., Castro, D., Navas, J.I., Borrego, J.J., 1999. Phagocytic and chemotactic responses of manila and carpet shell clam haemocytes against Vibrio tapetis, the causative agent of brown ring disease. Fish Shellfish Immunol. 9, 543555.

Mar Costa, M., Novoa, B., Figueras, A., 2008. Influence of $\beta$-glucans on the immune responses of carpet shell clam ( Ruditapes decussatus) and Mediterranean mussel (Mytilus galloprovincialis). Fish Shellfish Immunol. 24, 498-505.

Matozzo, V., Ballarin, L., Pampanin, D.M., Marin, M.G., 2001. Effects of copper and cadmium exposure on functional responses of hemocytes in the clam, Tapes philippinarum. Arch. Environ. Contam. Toxicol. 41, 163-170.

Matozzo, V., Da Ros, L., Ballarin, L., Meneghetti, F., Marin, M.G., 2003. Functional responses of haemocytes in the clam Tapes philippinarum from the Lagoon of Venice: fishing impact and seasonal variations. Can. J. Fish. Aquat. Sci. 60, 949958.

Matozzo, V., Monari, M., Foschi, J., Serrazanetti, G.P., Cattani, O., Marin, M.G., 2007. Effects of salinity on the clam Chamelea gallina. Part I: alterations in immune responses. Mar. Biol. 151, 1051-1058.

Matozzo, V., Marin, M.G., Cima, F., Ballarin, L., 2008. First evidence of cell division in circulating haemocytes from the manila clam Tapes philippinarum. Cell Biol. Int. 32, 865-868.

Matsumoto, T., Nakamura, A.M., Takahashi, K.G., 2006. Cloning of cDNAs and hybridization analysis of lysozymes from two oyster species, Crassostrea gigas and Ostrea edulis. Comp. Biochem. Physiol. 145B, 325-330.

McHenery, J.G., Birkbeck, T.H., 1985. Uptake and processing of cultured microorganisms by bivalves. J. Exp. Mar. Biol. Ecol. 90, 145-163. 
McHenery, J.G., Allen, J.A., Birkbeck, T.H., 1986. Distribution of lysozyme-like activity in 30 bivalve species. Comp. Biochem. Physiol. 85B, 581-584.

Mochizuki, A., Matsumira, M., 1983. Lysozyme activity in shellfishes. Bull. Jpn. Soc. Sci. Fish. 49, $131-135$.

Monari, M., Matozzo, V., Foschi, J., Cattani, O., Serrazanetti, G., Marin, M., 2007. Effects of high temperatures on functional responses of haemocytes in the clam Chamelea gallina. Fish Shellfish Immunol. 22, 98-114.

Montes, J.F., Mercè, D., Garcia-Valero, J., 1995a. Cellular defense mechanism of the clam Tapes semidecussatus against infection by the protozoan Perkinsus sp. Cell Tissue Res. 279, 529-538.

Montes, J.F., Mercè, D., Garcia-Valero, J., 1995b. Characterization and localization of an Mr 225 kDa polypeptide specifically involved in the defense mechanisms of the clam Tapes semidecussatus. Cell Tissue Res. 280, 27-37.

Montes, J.F., Durfort, M., Garcia-Valero, J., 1996. When the venerid clam Tapes decussatus is parasitized by the protozoan Perkinsus sp. it synthesizes a defensive polypeptide that is closely related to p225. Dis. Aquat. Org. 26, $149-157$.

Morvan, A., 1991. "Caractérisation antigénique des hémocytes de l'huitre Crassostrea gigas et analyse de leur activité antiinfectieuse oxygène-dépendante." D.E.A. Thesis, Université Bordeaux II. In French.

Mount, A.S., Wheeler, A.P., Paradkar, R.P., Snider, D., 2004. Hemocyte-mediated shell mineralization in the eastern oyster. Science 304, 297-300.

Murphy, M.P., 2009. How mitochondria produce reactive oxygen species. Biochem. J. 417, 1-13.

Naik, S.H., 2008.Demystifying the development of dendritic cell subtypes, a little. Immunol. Cell Biol. 86, 439-452.

Nauseef,W.M., 2008. Nox enzymes in immune cells. Semin. Immunopathol. 30, 195-208. Ng, T.Y.T., Wang, W.X., 2004. Detoxification and effects of $\mathrm{Ag}, \mathrm{Cd}$, and $\mathrm{Zn}$ pre-exposure on metal uptake kinetics in the clam Ruditapes philippinarum. Mar. Ecol., Progr. Ser. 268, 161-172.

Noël, D., Boulo, V., Chagot, D., Mialhe, E., 1991. Preparation and characterization of monoclonal antibodies against neoplastic hemocytes of Mytilus edulis. Dis. Aquat. Org. 10, 51-58.

Noël, D., Pipe, R., Elston, R., Bachère, E., Mialhe, E., 1994. Antigenic characterization of hemocyte subpopulations in the mussel Mytilus edulis by means of monoclonal antibodies. Mar. Biol. 119, 549-556.

Nyholm, S.V., Passegue, E., Ludington, W.B., Voskoboynik, A., Mitchel, K., Weissman, I.L., De Tomaso, A.W., 2006. fester, A candidate allorecognition receptor from a primitive chordate. Immunity 25, 163-173.

Ordás, M.C., Ordás, A., Beloso, C., Figueras, A., 2000a. Immune parameters in carpet shell clams naturally infected with Perkinsus atlanticus. Fish Shellfish Immunol. 10, 597-609.

Ordás, M.C., Novoa, B., Figueras, A., 2000b. Modulation of the chemiluminescence response of Mediterranean mussel (Mytilus galloprovincialis) haemocytes. Fish Shellfish Immunol. 10, 611-622.

Ottaviani, E., Franchini, A., Malagoli, D., Genedani, S., 2000. Immunomodulation by recombinant human interleukin-8 and its signal transduction pathways in invertebrate hemocytes. Cell Mol. Life Sci. 57, 506-513.

Paillard, C., 2004. A short-review of brown ring disease, a vibriosis affecting clams, Ruditapes philippinarum and Ruditapes decussatus. Aquat. Living Resour. 17, 467-475.

Paillard, C., Percelay, L., Le Pennec, M., Le Picard, D., 1989. Pathogenic origin of the "brown ring" in Tapes philippinarum, Mollusca, Bivalvia. C.R. Acad. Sci. Ser. III 309, 235-241.

Paillard, C., Le Roux, F., Borrego, J.J., 2004a. Bacterial disease in marine bivalves, a review of recent studies: trends and evolution. Aquat. Living Resour. 17, 477-498.

Paillard, C., Allam, B., Oubella, R., 2004b. Effect of temperature on defense parameters in manila clam Ruditapes philippinarum challenged with Vibrio tapetis. Dis. Aquat. Org. 59, 249-262.

Park, K.I., Choi, K.S., 2001. Spatial distribution of the protozoan parasite Perkinsus sp. found in the manila clams, Ruditapes philippinarum, in Korea. Aquaculture 203, 9-22.

Park, K.I., Choi, K.S., Choi, J.W., 1999. Epizootiology of Perkinsus sp. found in the Manila clam, Ruditapes philippinarum in Komsoe Bay, Korea. J. Korean Fish. Soc. 32, 303-309.

Park, K.I., Paillard, C., Le Chevalier, P., Choi, K.S., 2006. Report on the occurrence of brown ring disease (BRD) in Manila clam, Ruditapes philippinarum, on the west coast of Korea. Aquaculture 255, 610-613.

Pipe, R.K., 1992. Generation of reactive oxygen metabolites by the haemocytes of the mussel Mytilus edulis. Dev. Comp. Immunol. 16, 111-122.

Pipe, R.K., Coles, J.A., 1995. Environmental contaminants influencing immune function in marine bivalve molluscs. Fish Shellfish Immunol. 5, 581-595.

Prado-Alvarez, M., Gestal, C., Novoa, B., Figueras, A., 2008. Differentially expressed genes of the carpet shell clam Ruditapes decussatus against Perkinsus olseni. Fish Shellfish Immunol. 26, 72-83.

Rajesh Kumar, S., Ishaq Ahamed, V.P., Sarathi, M., Nazeer Basha, A., Sahul Hameed, A.S., 2008. Immunological responses of Penaeus monodon to DNA vaccine and its efficacy to protect shrimp against white spot syndrome virus (WSSV). Fish Shellfish Immunol. 24, 467-478.

Reid, H., Soudant, P., Lambert, C., Paillard, C., Birkbeck, T.H., 2003. Salinity effect on immune parameters of Ruditapes philippinarum challenged with Vibrio tapetis. Dis. Aquat. Organ. 56, 249-258.

Renault, T., Xue, Q.G., Chilmonczyk, S., 2001. Flow cytometric analysis of European flat oyster, Ostrea edulis, haemocytes using a monoclonal antibody specific for granulocytes. Fish Shellfish Immunol. 11, 269-274.

Rifi, M., 2005. "Etude de la production d'Espèces Oxygénées Réactives (EOR) par les hémocytes de la palourde japonaise Ruditapes philippinarum" [Study on Reactive Oxygen Species (ROS) production by hemocytes of Manila clam Ruditapes philippinarum]. Master of Science Thesis, University of Bretagne Occidentale, Brest, France. In French.

Rowley, A.F., Powell, A., 2007. Invertebrate immune systems-specific, quasi-specific, or nonspecific? J. Immunol. 179, 72097214. 
Sagristà, E., Durfort, M., Azevedo, C., 1995. Perkinsus sp. (Phylum Apicomplexa) in Mediterranean clam Ruditapes semidecussatus: ultrastructural observations of the cellular response of the host. Aquaculture 132, 153-160.

Schneeweiss, H., Renwrantz, L., 1993. Analysis of the attraction of haemocytes from Mytilus edulis by molecules of bacterial origin. Dev. Comp. Immunol. 17, 377-387.

Segal, A., 2008. The function of the NADPH oxidase of phagocytes and its relationship to other NOXs in plants, invertebrates, and mammals. Int. J. Biochem. Cell Biol. 40, 604-618.

Shumway, S.E., 1990. A review of the effects of algal blooms on shellfish and aquaculture. J. World Aquac. Soc. 21, 65-104.

Smayda, T.J., 1997a. Harmful algal blooms: their ecophysiology and general relevance to phytoplankton blooms in the sea. Limnol. Oceanogr. 42, 1137-1153.

Smayda, T.J., 1997b. What is a bloom? A commentary. Limnol. Oceanogr. 42, 1132-1136.

Soudant, P., Paillard, C., Choquet, G., Lambert, C., Reid, H.I., Marhic, A., Donaghy, L., Birkbeck, T.H., 2004. Impact of season and rearing site on the physiological and immunological parameters of the manila clam Venerupis (=Tapes,=Ruditapes) philippinarum. Aquaculture 229, 401-418.

Soudant, P., Leite, R., Chu, F.L.E., Villalba, A., Cancela, L., 2008. Bivalves-Perkinsus spp. interactions. In: Villalba, Antonio (Ed.), Workshop for the analysis of the impact of Perkinsosis to the European Shellfish Industry, Vilanova de Arousa, Spain.

Steinert, S.A., Pickwell, G.V., 1985. Multiple forms of lysozyme in copper stressed mussels (Mytilus edulis). Mar. Environ. Res. $17,211-214$

Sun, J., Wu, X., Zhang, W., 2006. Morphological, structural and functional characteristics of the hemocytes of the oyster, Crassostrea ariakensis. J. Shellfish Res. 25, 55-64.

Taieb, J., Chaput, N., Ménard, C., Apetoh, L., Ullrich, E., Bonmort, M., Péquignot, M., Casares, N., Terme, M., Flament, C., Opolon, P., Lecluse, Y., Métivier, D., Tomasello, E., Vivier, E., Ghiringhelli, F., Martin, F., Klatzmann, D., Poynard, T., Tursz, T., Raposo, G., Yagita, H., Ryffel, B., Kroemer, G., Zitvogel, L., 2006. A novel dendritic cell subset involved in tumor immunosurveillance. Nat. Med. 12, 214-219.

Takahashi, K.G., Mori, K., Nomura, T., 1986. Occurrence and characterisation of lysozyme from marine bivalves. Bull. Jpn. Soc. Fish. 52, 863-868.

Takahashi, K.G., Kuroda, T., Muroga, K., 2008. Purification and antibacterial characterization of a novel isoform of the manila clam lectin (mcl-4) from the plasma of the manila clam, Ruditapes philippinarum. Comp. Biochem. Physiol. B Biochem. Mol. Biol. 150, 45-52.

Terahara, K., Takahashi, K.G., 2008. Mechanisms and immunological roles of apoptosis in molluscs. Curr. Pharm. Des. 14, 131-137.

Toreilles, J., Guérin, M.C., Roch, P., 1996. Reactive oxygen species and defense mechanisms in marine bivalves. C. R. Acad. Sci. Ser. III 319, 209-218 in French.

Travers, M.A., da Silva, M.P., Le Goïc, N., Marie, D., Donval, A., Huchette, S., Paillard, C., Koken, M., 2008. Morphologic, cytometric and functional characterisation of abalone (Haliotis tuberculata) haemocytes. Fish Shellfish Immunol. 24, 400-411.

Volety, A.K., Chu, F.L.E., 1995. Suppression of chemiluminescence of eastern oyster (Crassostrea virginica) hemocytes by the protozoan parasite Perkinsus marinus. Dev. Comp. Immunol. 19, 135-142.

Volety, A.K., Winstead, J.T., Fisher, W.S., 1999. Influence of seasonal factors on oyster hemocyte killing of Vibrio parahaemolyticus. J. Shellfish Res. 18, 323.

Vosshenrich, C.A.J., Lesjean-Pottier, S., Hasan, M., Richard-Le Goff, O., Corcuff, E., Mandelboim, O., Di Santo, J.P., 2008. CD11cloB220+ interferon-producing killer dendritic cells are activated natural killer cells. J. Exp. Med. 204, 2569-2578.

Witteveldt, J., Vlak, J.M., van Hulten, M.C.W., 2004. Protection of Penaeus monodon against white spot syndrome virus using a WSSV subunit vaccine. Fish Shellfish Immunol. 16, 571-579.

Witteveldt, J., Vlak, J.M., van Hulten, M.C.W., 2006. Increased tolerance of Litopenaeus vannamei to white spot syndrome virus (WSSV) infection after oral application of the viral envelope protein VP28. Dis. Aquat. Org. 70, 167-170.

Xing, J., Zhan, W., 2005. Characterisation of monoclonal antibodies to haemocyte types of scallop (Chlamys farreri). Fish Shellfish Immunol. 19, 17-25.

Xing, J., Zhan, W., 2006. Comparison of antigenicity among haemocytes of seven bivalve species by monoclonal antibodies against haemocytes of scallop (Chlamys farreri). Fish Shellfish Immunol. 20, 528-535.

Xue, Q., Renault, T., 2001. Monoclonal antibodies to European flat oyster Ostrea edulis hemocytes: characterization and tissue distribution of granulocytes in adults and developing animals. Dev. Comp. Immunol. 25, 187-194.

Xue, Q.G., Renault, T., Chilmonczyk, S., 2001. Flow cytometric assessment of haemocyte sub-populations in the European flat oyster, Ostrea edulis, haemolymph. Fish Shellfish Immunol. 11, 557-567.

Xue, Q.G., Itoh, N., Schey, K.L., Li, Y.L., Cooper, R.K., La Peyre, J.F., 2007. A new lysozyme from the eastern oyster (Crassostrea virginica) indicates adaptative evolution of i-type lysozymes. Cell. Mol. Life Sci. 64, 82-95.

Zhang, Y., Ren, S., Wang, D., Song, W., 2005. Structure and classification of haemocytes in the bivalve mollusc Meretrix meretrix. J. Ocean Univ. China 5, 132-136.

Zhou, Q., Zhang, J., Fu, J., Shi, J., Jiang, G., 2008. Biomonitoring: an appealing tool for assessment of metal pollution in the aquatic ecosystem. Anal. Chim. Acta 606, 135-150. 


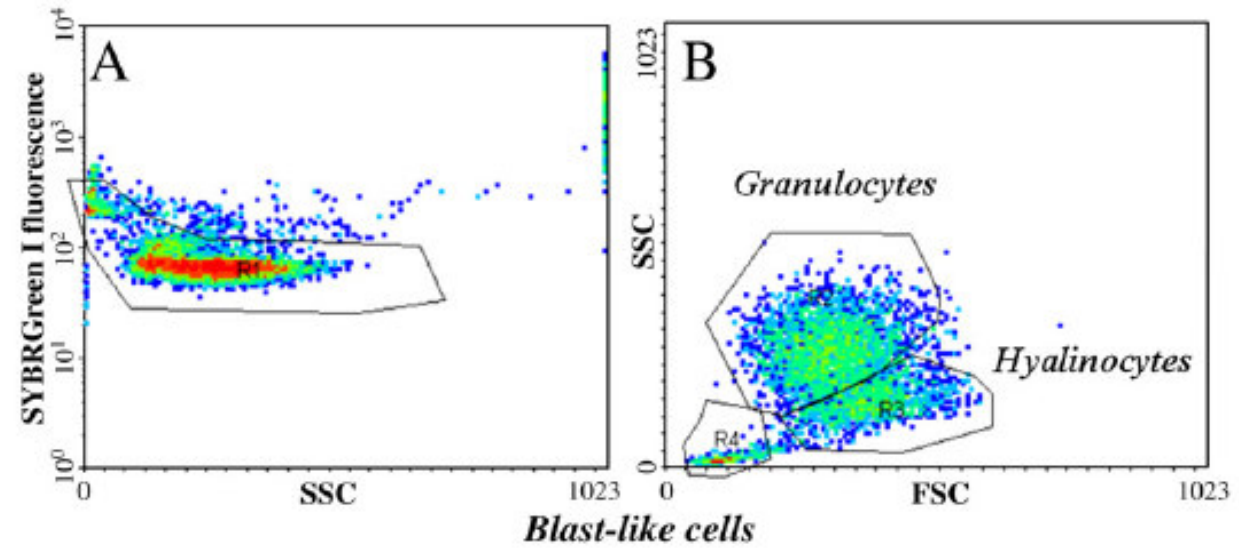

Fig. 1. Flow cytometric analysis of hemocyte sub-populations from R. philippinarum. (A) Internal complexity (side scatter=SSC) against SYBR Green I fluorescence density plot. Single cells were gated in region R1, excluding aggregated cells. (B) SSC against Size (forward scatter=FSC) density plot of hemocytes "gated" in region R1 (A). Three subpopulations of hemocytes were distinguishable: granulocytes, hyalinocytes and blast-like cells.

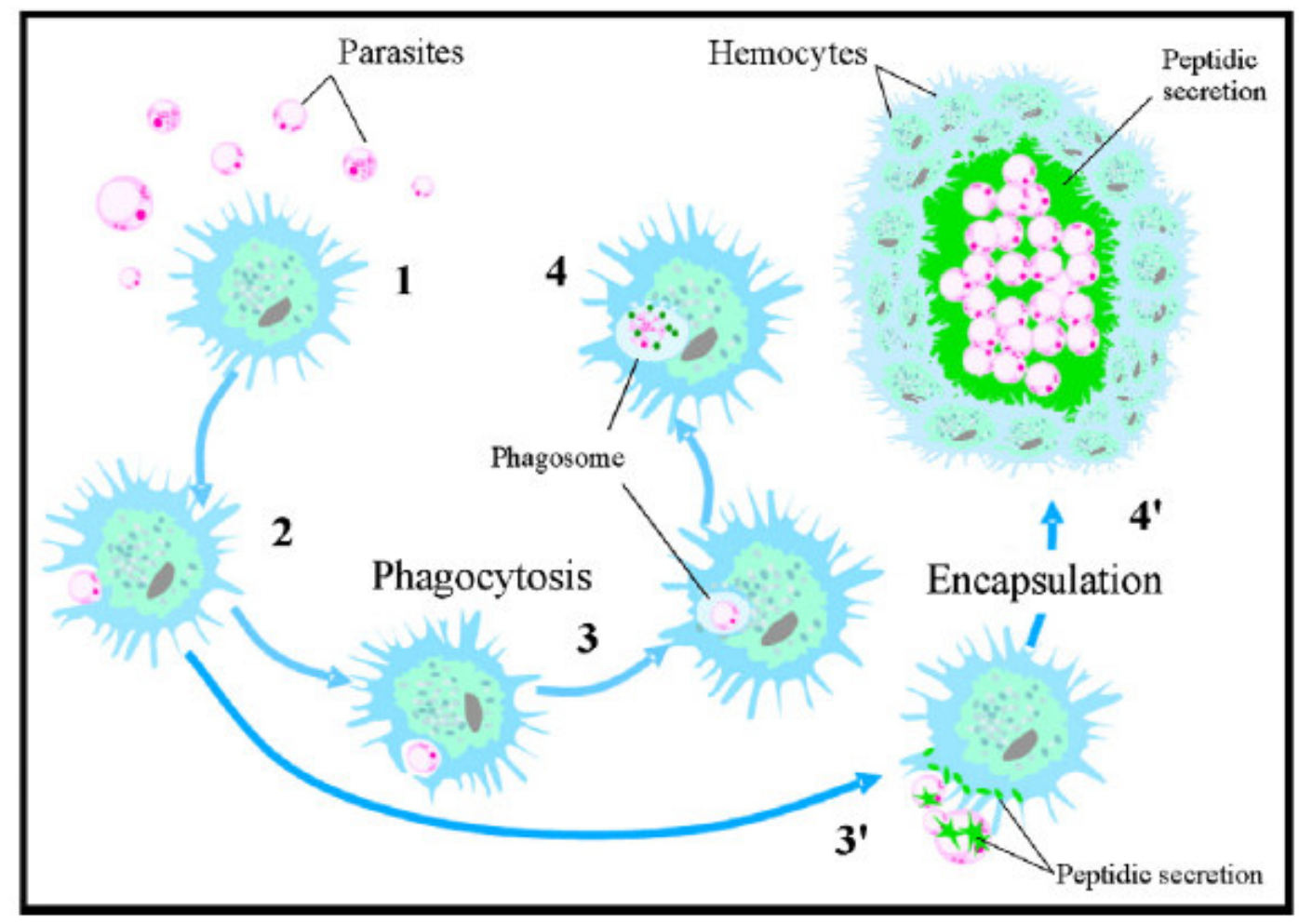

Fig. 2. Schematic presentation of putative cellular response in clam defense mechanisms upon microbial infection and parasitism. Adapted from Soudant et al., 2008. 1. Chemotaxis, attraction and migration to non-self material; 2. Recognition and attachment of invading micro-organisms; 3. Internalization of micro-organisms into a phagosome; 4. The microorganism may be destroyed by oxygen dependent and oxygen-independent microbicidal activities. These four steps constitute the so-called phagocytosis process. However, at step $3^{\prime}$ hemocytes can encapsulate the micro-organisms; 4'. Eventually, encapsulated micro-organisms can be destroyed extracellularly. 


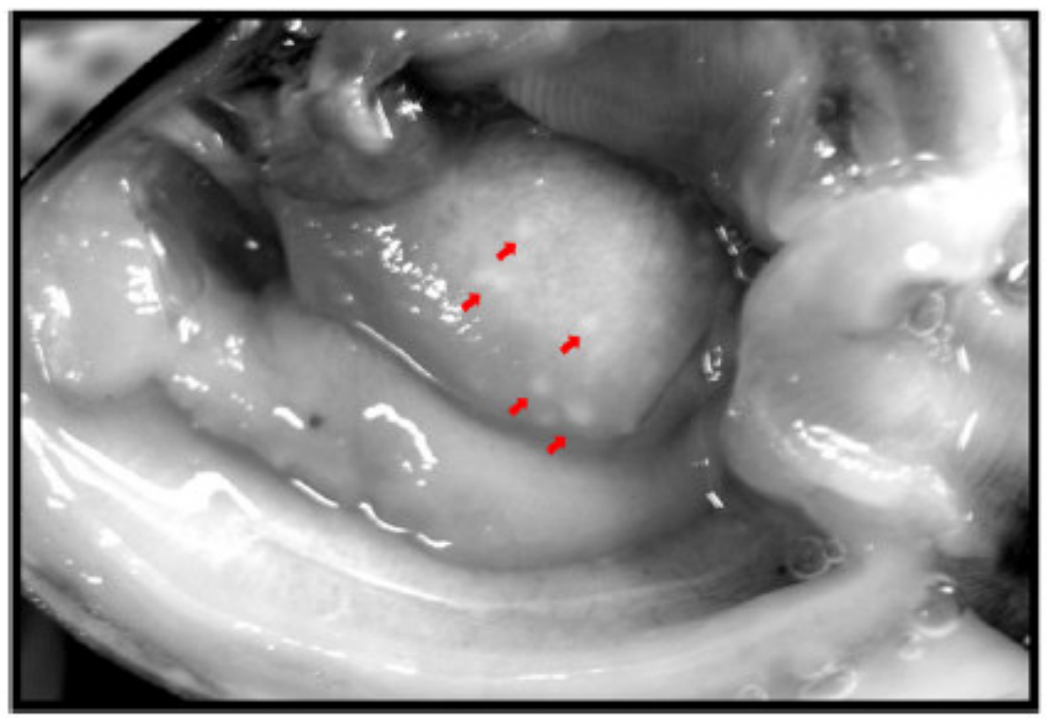

Fig. 3. Macroscopic observation of milky white nodules (red arrows) on the surface of $R$. philippinarum body.

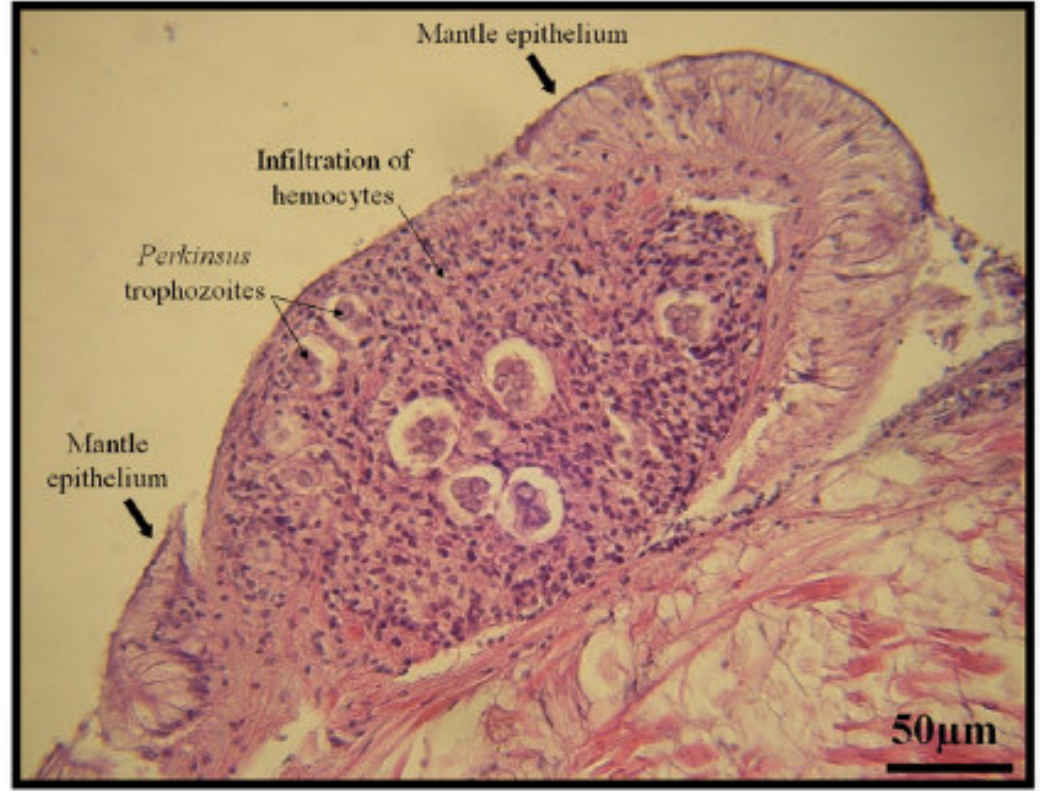

Fig. 4. Histological observation of granuloma structure in the connective tissue of the mantle of $R$. philippinarum. A massive infiltration of hemocytes was observed around Perkinsus parasite trophozoites, disrupting the tissular structure of the mantle. 


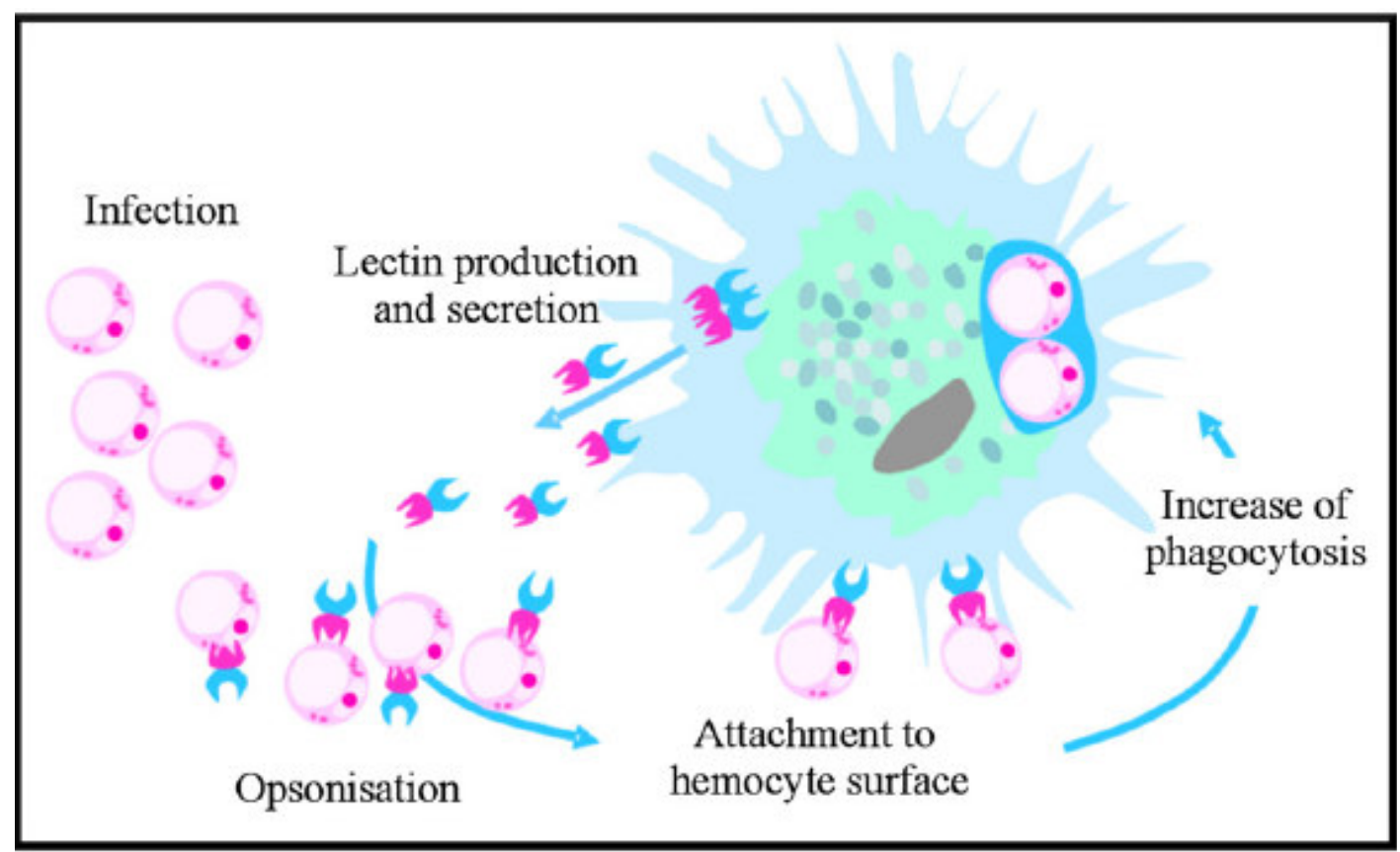

Fig. 5. Hypothetical process of how lectins affect recognition and elimination of parasites by hemocytes in clams. Adapted from Soudant et al., 2008.

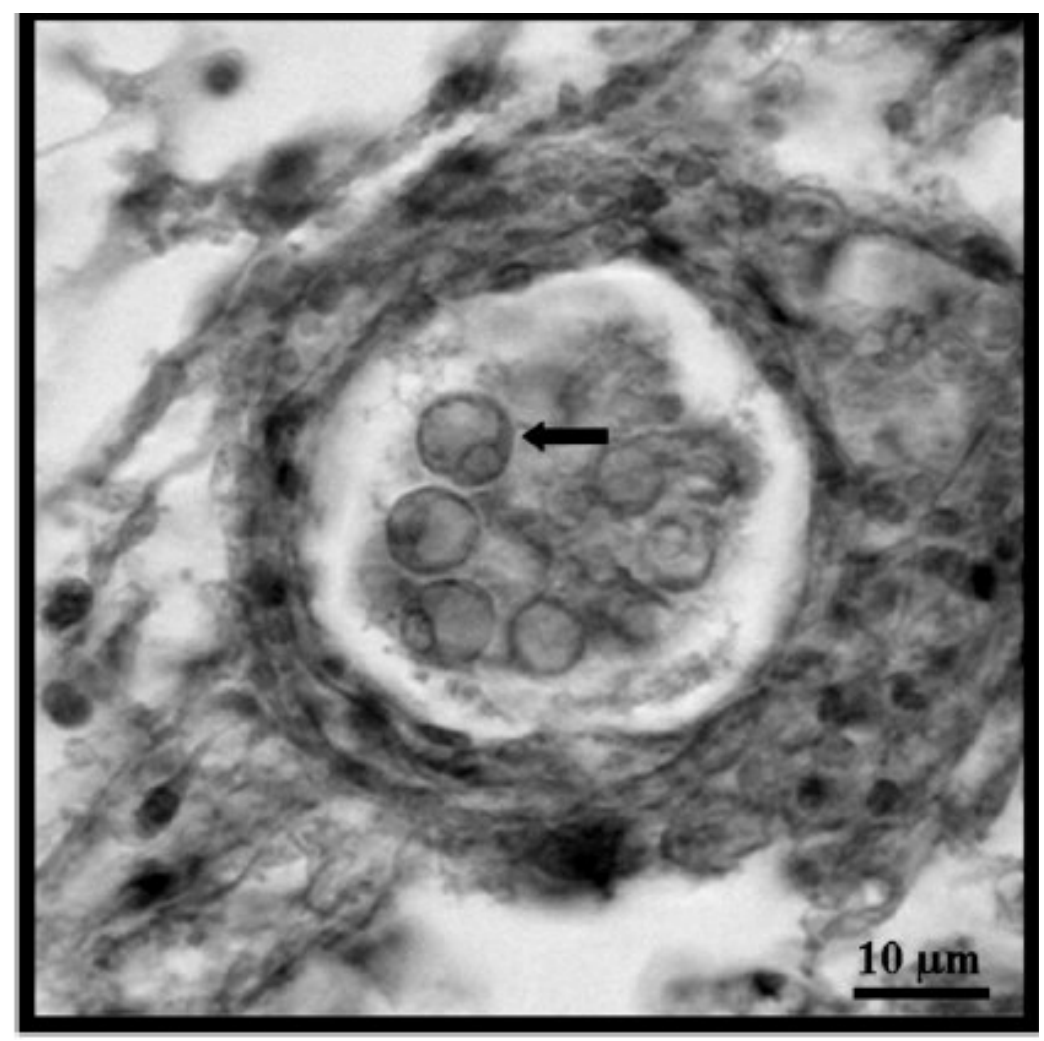

Fig. 6. Encapsulation of Perkinsus trophozoites in R. philippinarum tissues. Perkinsus trophozoites (arrow) were surrounded by infiltrated hemocytes in granuloma structure. 


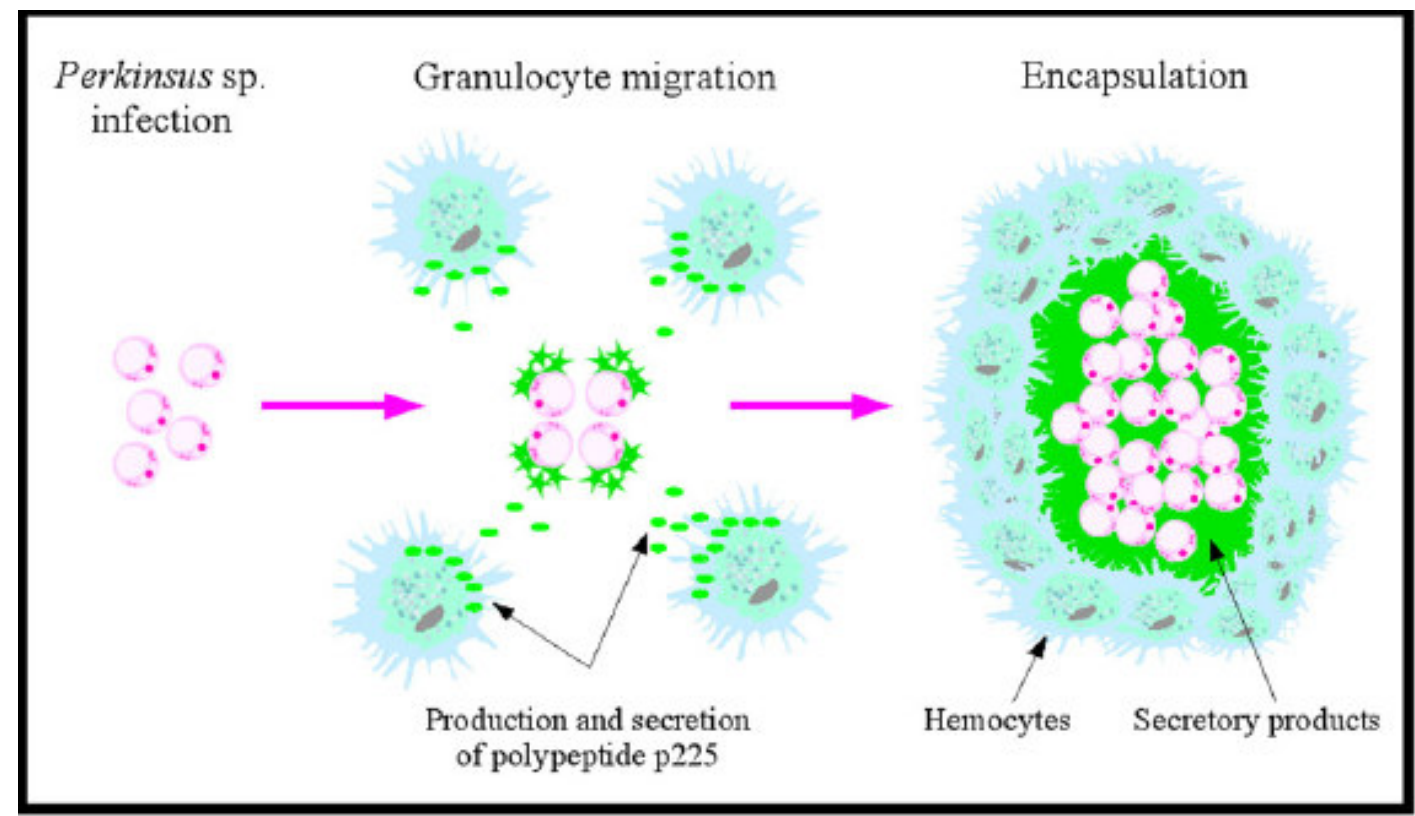

Fig. 7. Schematic representation of Perkinsus sp. encapsulation by the hemocytes of clams ( $R$. decussatus and $R$. philippinarum) according to the studies of Montes et al. 1995a,b, 1996. Adapted from Soudant et al., 2008.

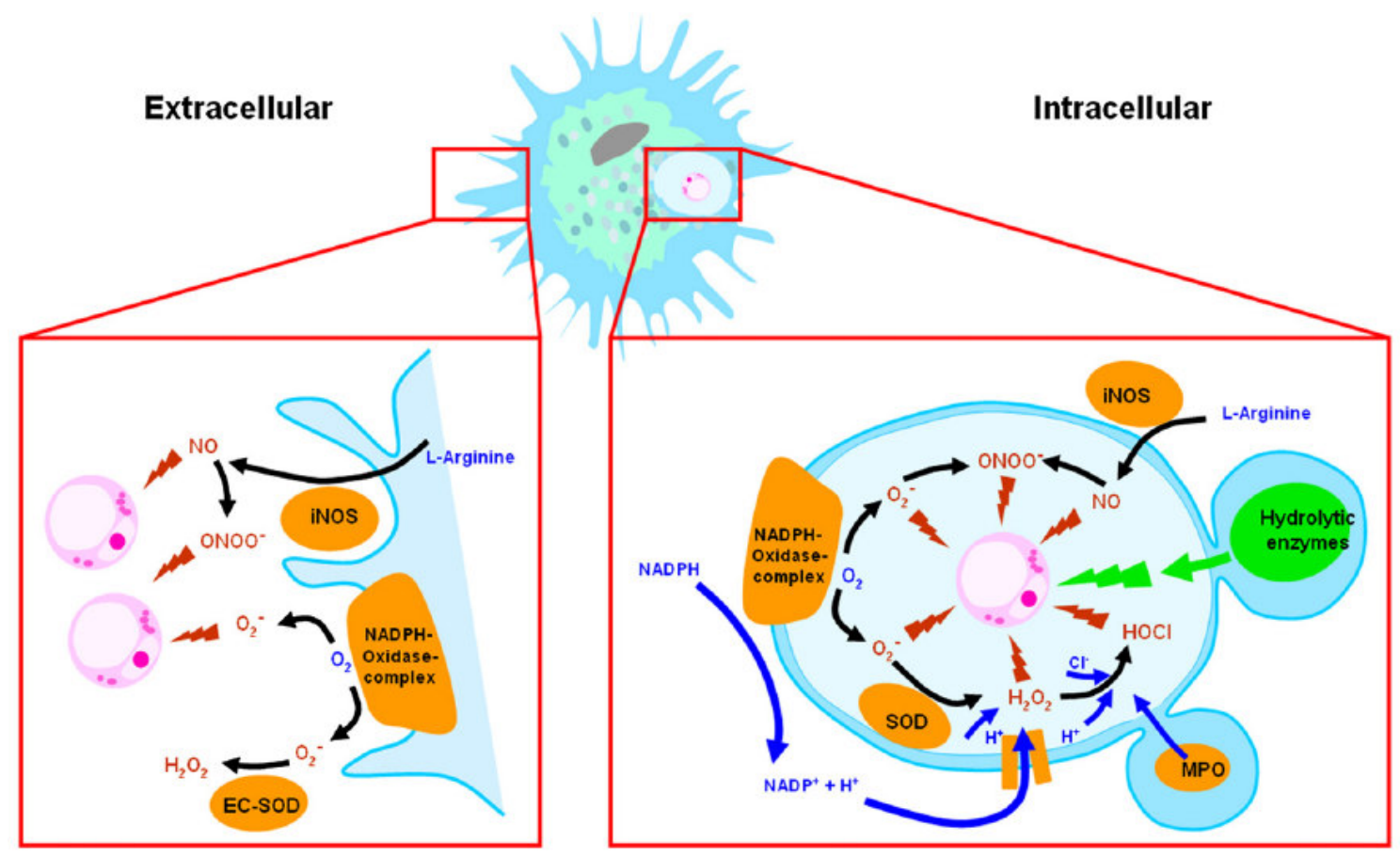

Fig. 8. Commonly admitted pathways involved in production of major reactive oxygen species and nitrogen species outside the cell membrane (left) and inside phagosome (right) in hemocytes of bivalves. Soudant et al., 2008. NO, Nitric oxide; ONOO-, peroxynitrite; $\mathrm{O} 2$-, Anion superoxide; $\mathrm{HOCl}$, Hypochloride; iNOS, inductible nitric oxide synthase; SOD, superoxide dismutase; EC-SOD, Extracellular superoxide dismutase; MPO, myeloperoxidase. 